\title{
CRISIS DE LA CIVILIZACIÓN OCCIDENTAL CAPITALISTA Y MOVIMIENTOS ANTISISTÉMICOS
}

\section{Agustin Lao-Montes}

Universidad de Massachusetts

\section{Resumen:}

En este texto el autor presenta una definición de la crisis de la civilización occidental, indaga en sus orígenes y propone una relación con la colonialidad del poder y la modernidad capitalista. Explora de la crisis sus expresiones culturales, ecológicas, alimentarias y energéticas, así como sus implicaciones en la democracia liberal frente a la Nueva Ola de Movimientos Antisistémicos.

\section{Palabras Claves:}

Globalización, capitalismo, crisis, descolonización, antisistémico.

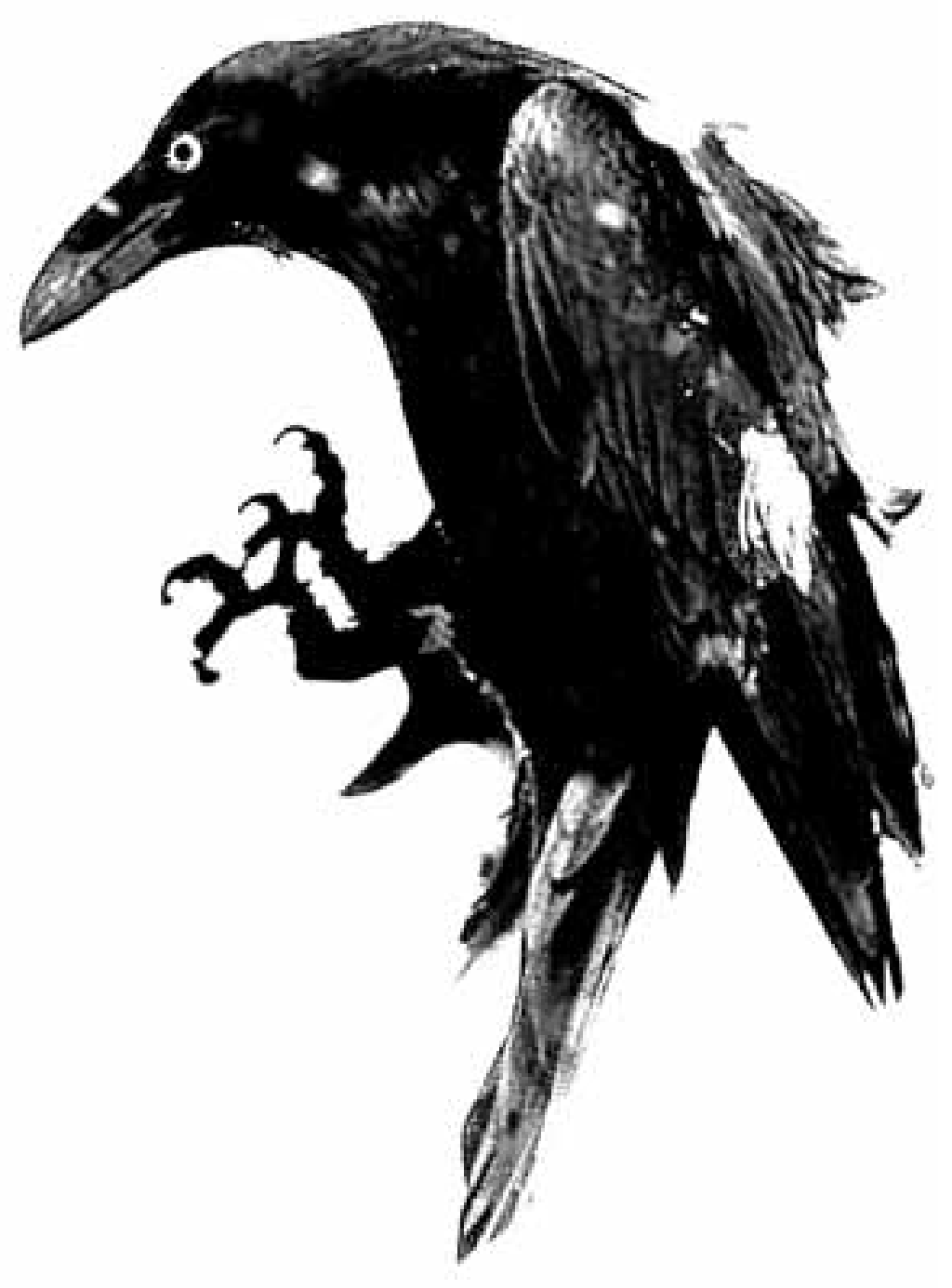


"Cuando a los Estados Unidos le da catarro a nosotros nos da pulmonía"

Maurice Bishop

"Cada expresión de la Civilización Occidental es a la vez una expresión de Barbarie"

Walter Benjamin

"Sin lucha no hay progreso"

Frederick Douglass

En la oración que abre el clásico del pensamiento des/colonial Discurso sobre el Colonialismo, el intelectual Afro-Caribeño, Aime Cesaire declara que "Una civilización que se prueba incapaz de resolver los problemas que crea es una civilización decadente."' De inmediato añade que "una civilización que decide cerrar sus ojos a sus problemas más cruciales es una civilización enferma" y que "una civilización que usa sus principios para trampa y engaño, es una civilización muriente.” Cesaire escribía esto en 1955, luego de la gran depresión de los años 30 y de dos grandes guerras de occidente, y en el contexto de una ola ascendente de movimientos en Asia, África y el Caribe por la descolonización de los imperios europeos que imperaban desde el largo siglo XVI. Hoy día, 55 años más tarde, podemos decir que fue una aseveración profética si lo consideramos como pronóstico de la crisis actual de la civilización occidental capitalista.

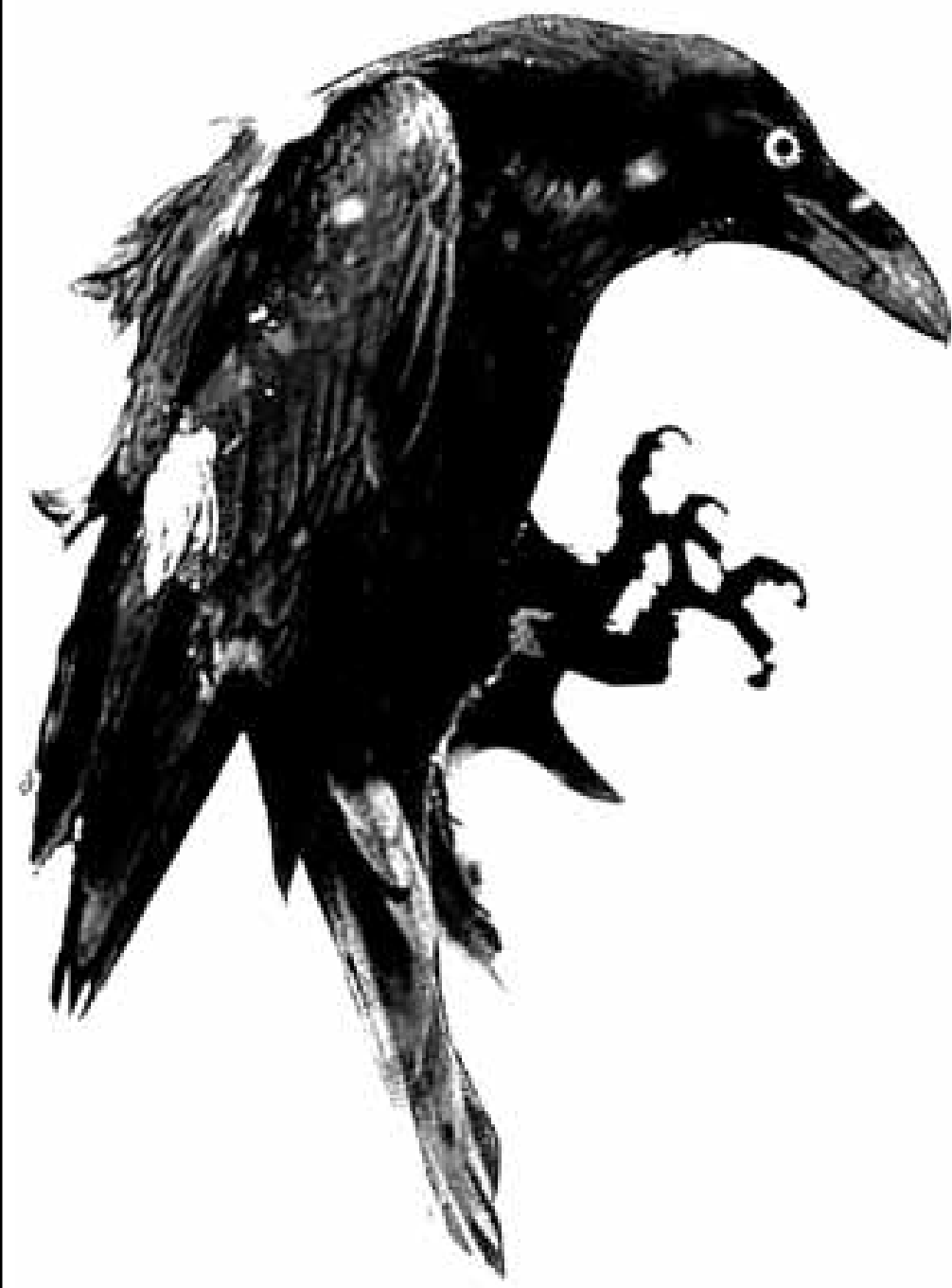

A contracorriente de las promesas de pronta recuperación que escuchamos de presidentes como García en Perú y Obama en los Estados Unidos, las imágenes cotidianas y más mediáticas de millones de personas desempleadas, desterradas, familias sin hogar, hambrunas y epidemias masivas, violencias múltiples (étnico-racial, religiosa, sexual, doméstica, geo-política, genocidios, guerras); expresan una condición de malestar profundo que caracterizamos como crisis. Los síntomas de crisis global se componen con movilizaciones y huelgas generales desde Francia, Grecia, Irlanda e India, hasta Martinica y Portugal, y con despidos masivos en Puerto Rico y Cuba. A la vez salen al relieve 20 millones de desamparados en Pakistán producto de una serie de inundaciones y casi un país entero en la calle en Haití muchos sufriendo del cólera luego de un terremoto devastador, ambas situaciones resultantes de desastres alegadamente naturales que son al menos parcialmente causados por la crisis ecológica y exacerbados por intervenciones militares del imperio estadounidense. A estas calamidades sumamos los genocidios en Darfur y Rwanda, mas el destierro masivo que ha dejado un resto de más de 4 millones de desplazados en Colombia, la gran mayoría Afrodescendientes e Indígenas. 
En este artículo haremos una especie de mapeo del momento actual y sus diversas interpretaciones, con el fin de caracterizar y explicar, a grosso modo, esta coyuntura de crisis global para así esbozar y analizar las resistencias y luchas que emergen como alternativas. Para esto es necesario comenzar explicando que entendemos por crisis, para luego deslindar distintas teorías de su carácter, emergencia, temporalidad, y sus posibles escenarios de resolución.

\section{¿Qué es la Crisis? Crisis como Categoría Político Epistémica}

Cuando hablamos de crisis nos referimos a una situación insostenible, que requiere cambios sustantivos, y nuestro argumento es que no solo la economía y la política sino también las lógicas culturales, éticas, epistémicas, y ecológicas del sistemamundo moderno/colonial capitalista se encuentran sumidas en esta condición. La palabra "crisis" se deriva del griego significando "ese momento liminar en el que se decide el desenlace de una dolencia, en el que el cuerpo escenifica el "juicio final' a partir del cual se impone definitivamente la enfermedad o la salud.”'En su filología griega, Krisis - “decisión”- procede de Krio - “yo separo, decido, juzgo"- y de ambos se desprende "crítica". Una crisis, pues, es esa situación en la que se dirime el destino y se revelan los límites de un organismo vivo o una estructura compleja. Por ende estar en crisis significa una coyuntura crítica en la que se decide la suerte del sistema mismo. Lo contrario de krisis es kairos, que en la filosofía griega y romana era la "oportunidad", el "momento justo", la grieta temporal de la intervención divina. La krisis es también nuestro kairos. Por eso, en un artículo titulado Mi nombre es crisis, el teólogo de la liberación Frei Betto dice "Mi nombre deriva del griego krisis, discernir, escoger, distinguir, en fin tener ojos críticos. Tengo familiaridad también con el verbo acrisolar, purificar. Contra lo que supone el sentido común, no soy, en sí, negativa. Formo parte de la evolución de la naturaleza. Tengo dos caras." ${ }^{3}$ Por ende, las crisis sistémicas se deben entender como momentos de grandes riesgos y sufrimientos para la mayoría de la humanidad, largas coyunturas de hambrunas, desempleos, guerras, violencias múltiples, perdidas de vida y recursos; pero también como periodos de emergencia de nuevos modos de vida y de insurgencia de movimientos y alternativas libertarias y de equidad. En ese sentido se podrían entender tanto a partir del concepto naturista de "crisis curativas" como a través de la noción de Schumpeter de "destrucción creativa” ya que implican tanto destrucción de lo viejo como creación de algo nuevo.

En resumen, el concepto crisis representa condiciones en la cuales se imponen transformaciones estructurales ya que las formas y normas fundamentales de funcionamiento de un sistema social no solo no funcionan bien, pero lo que es peor generan situaciones de caos, malestar colectivo, carencias, violencias y resistencias. ¿De donde surgen históricamente estas situaciones de crisis?, ¿cuál es su carácter?, ¿Cuáles son sus dinámicas principales?, ¿qué hacer? 


\section{Teorías de las Crisis y sus Implicaciones Políticas}

La cuestión de las crisis constituye un campo político epistémico clave en la teoría crítica y en perspectivas políticas tanto radicales como reformistas. Dentro de las tradiciones marxistas y social-demócratas, podemos hablar de teorías de las crisis como un hito tanto en las maneras de teorizar el capitalismo como en las políticas en aras de la creación ya sea de un capitalismo reformado (con cara más humana) o de proyectos socialistas y/o poscapitalistas. Por ejemplo, en los debates marxistas de la segunda y tercera internacional, uno de los temas nodales fue cómo explicar las crisis del capitalismo y que implicaciones dichas explicaciones tenían para las estrategias de lucha, procesos de cambio, y proyecto histórico. En dicho contexto, un contrapunto revelador es por un lado el "socialismo evolucionario" de Bernstein y la tesis de que el sistema va a caer por sus propias contradicciones; en contraste, por otro lado, tanto con el espontaneísmo de Rosa de Luxemburgo, y el vanguardismo partidista de Lenin, que convergían en entender la resolución de la crisis a partir de la agencia histórica de los sujetos (individuos, colectividades, organizaciones) a pesar de sus grandes diferencias. Es decir, tanto para Lenin como para Luxemburgo, la agencia colectiva en aras de transformación revolucionaria (ya sea a través de movilización de masas como en el concepto de Luxemburgo de huelga general, o de organización de partido de vanguardia en el caso de Lenin) es gestión imperativa en contextos de crisis. En contraste, las teorías de crisis como derrumbe económico y debacle histórico (como en Grossman y Kautsky), tendían a minimizar la importancia de las acciones colectivas y objetivizar (o reificar) tanto el carácter de la crisis como sus implicaciones políticas y posibles resoluciones. Esta forma de ver la crisis y sus posibilidades e implicaciones, también tiende a ofrecer explicaciones economicistas sobre el carácter y dinámica de las crisis sistémicas.

Al contrario, en este escrito esbozaremos los elementos para una analítica más compleja de la cuestión de la crisis en general y particularmente de la crisis actual donde se expliquen sus múltiples mediaciones, patrones y contingencias. Para esto es necesario explicitar rápidamente algunos asuntos teóricos de fondo que orientan este análisis de las crisis recurrentes del capitalismo y de la crisis actual en particular.

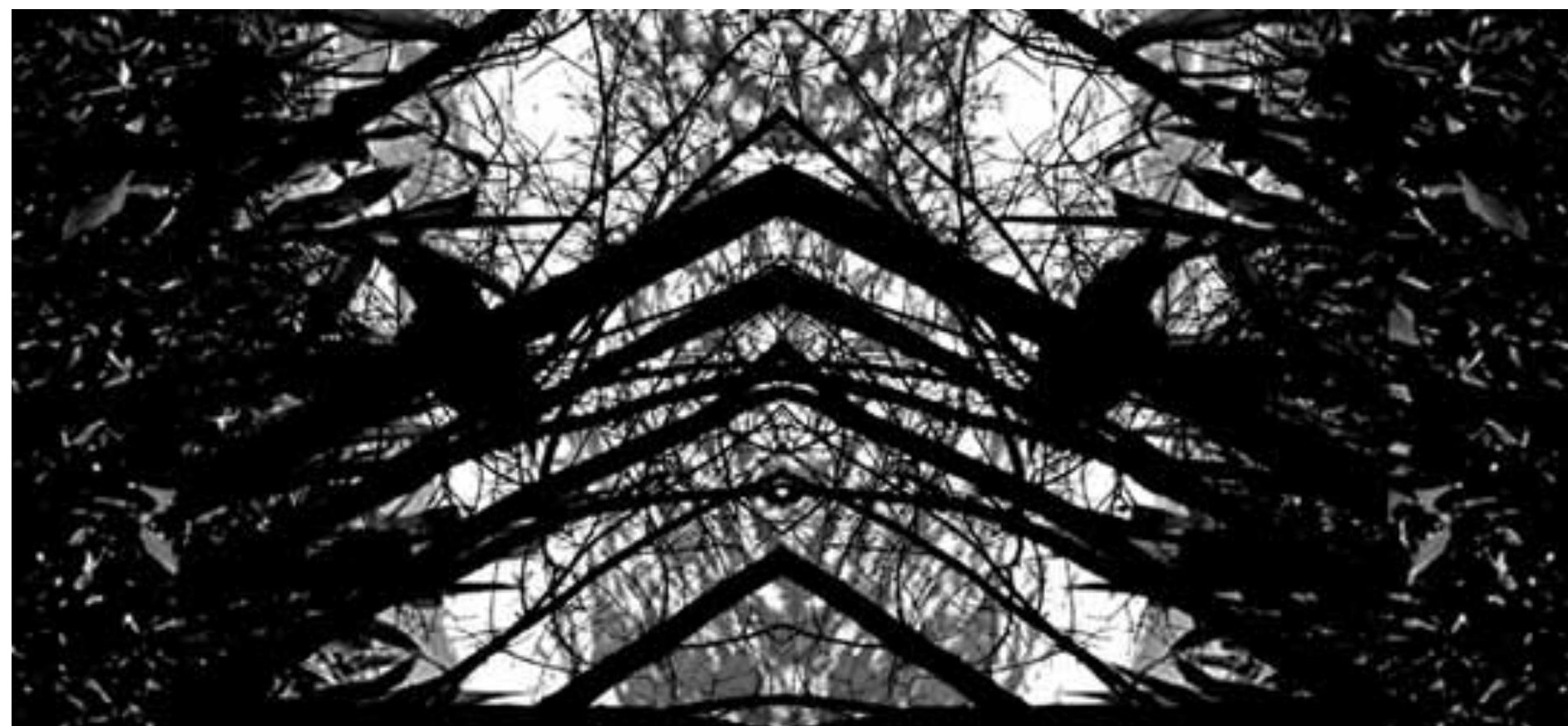




\section{Colonialidad del Poder y Modernidad Capitalista}

Para entender la crisis actual a profundidad es necesario un marco analítico claro, complejo y flexible, que nos permita ahondar en sus raíces de fondo, a la vez que nos facilite la posibilidad de indagar en sus matices y contradicciones. Aquí haremos un análisis breve de lo que denominamos crisis de la civilización occidental capitalista a partir de la analítica de la colonialidad del poder, perspectiva teórico-política cuyo autor inicial es el intelectual peruano Aníbal Quijano. ¿Que entendemos por colonialidad del poder? Quijano lo define como "un patrón de poder", es decir un entramado de relaciones que articula de manera compleja y desigual una multiplicidad de formas de dominación, explotación y conflicto en relación a la organización y apropiación de seis ámbitos fundamentales de la vida social: autoridad, comunicación, naturaleza, sexo, subjetividad, y trabajo. Dichos elementos están entrelazados a la vez que representan dimensiones particulares del espacio y proceso social. Otra estrategia de representación conceptual de la colonialidad del poder es como entrelace de cuatro regímenes modernos/coloniales de dominación, explotación y conflicto: capitalismo, racismo, imperialismo, y patriarcado.

El patrón de poder moderno/colonial debe entenderse como un proceso histórico-mundial que nace junto con la modernidad capitalista y que caracteriza fundamentalmente el proceso de globalización que surge en el largo Siglo XVI en el contexto de la conquista de las Américas, el comercio esclavista trans-Atlántico y la institucionalización del sistema de plantaciones, la emergencia de imperios europeos modernos y eventualmente un orden geopolítico basado en un sistema de naciones-estado, y la emergencia de la ideología de occidente como marco discursivo para darle sentido a las nuevas formas de dominación tanto religiosas y lingüísticas como culturales y epistémicas, lo cual implico la emergencia de nuevos modos de identificación e inter-subjetividad. Es en esta coyuntura histórico-mundial del largo siglo XVI cuando emerge el capitalismo centrado en el Atlántico, junto a las invenciones simultaneas de las Américas, África, y Europa en cuanto categorías geo-históricas continentales y regionales, que se crean las formas de clasificación y estratificación racial que conjugadas con las nuevos modos de explotación del trabajo subyugados a las dinámicas de acumulación de capital en el naciente mercado mundial, y con la redefinición del poder patriarcal, que se origina el patrón de colonialidad del poder que continua primando mundialmente hasta hoy. Denominamos las formas modernas de la dominación

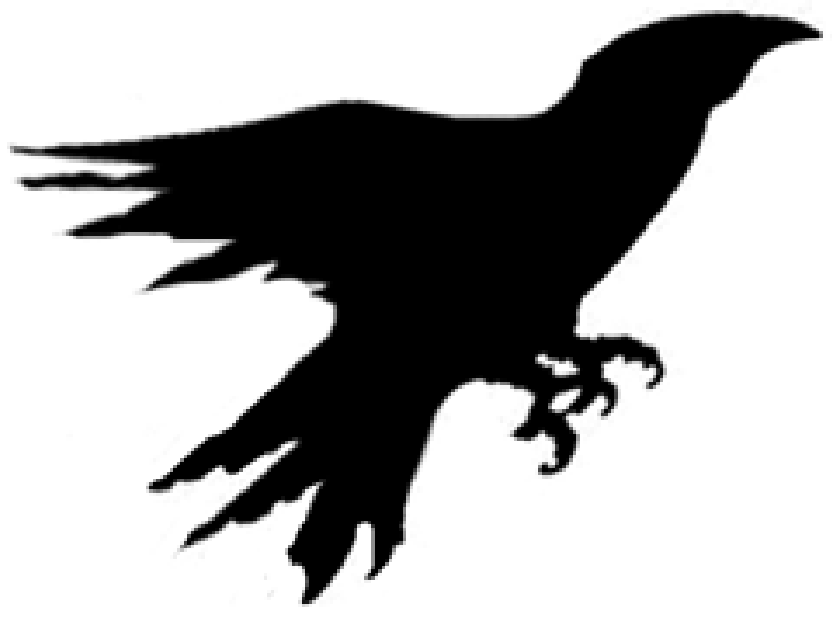


usando el sustantivo colonialidad para significar y acentuar no solo su origen colonial pero sobre todo la continuidad de estas jerarquías de poder y formas de desigualdad (económicas, geopolíticas, epistémicas, etno-raciales, sexuales, etc.) en el largo plazo de la historia de la modernidad capitalista.

Entendemos el poder no solo como dominación o como poder sobre, sino también como poder para y poder como capacidad e impulso vital humano tomando la definición de Enrique Dussel en su filosofía política de la liberación. ${ }^{4}$ En este sentido la cuestión del poder no solo se refiere a luchas contra regímenes de dominación sino también a modos de auto-afirmación y auto-creación de los sujetos históricos ${ }^{5}$ que construyen formas de vida distintas y alternativas al paradigma de vida moderno/ colonial y aquí está el meollo de lo que denominamos nueva política de descolonialidad y liberación.

Esta discusión nos lleva a caracterizar más precisamente nuestro objeto de análisis que es la condición presente como crisis de la civilización occidental capitalista.

\section{Crisis Civilizacional del Patrón de Poder Moderno/Colonial Capitalista}

Como resultado de esfuerzos colectivos de intelectuales-activistas sobre todo de América Latina y África, recientemente se sumo el rubro "Crisis de Civilización y Paradigmas Alternativos" como uno de los ejes transversales para el Foro Social Mundial a llevarse a cabo en Dakar, Senegal en Febrero, 2011. Hemos sido parte de este esfuerzo y entendemos que la manera más general y sintética que podemos caracterizar el momento presente es como una crisis de la Civilización Occidental Capitalista en su fase de globalización neoliberal, es decir una crisis del paradigma de vida moderno/colonial en sus múltiples dimensiones. Es decir, más que una simple crisis económica, hay problemas en todas las aristas del patrón de poder. Por eso es una crisis de un modo de vida con sus formas de economía, política, ecología, ética y conocimiento, ética, y subjetividad. Es una crisis de la modernidad capitalista que ha sido el patrón civilizacional dominante por más de 500 años.

Aquí cabe aclarar el sentido preciso que usamos el concepto de civilización dado que es una categoría polivalente y muchas de sus acepciones son contrarias al significado que le invertimos. Hay dos sentidos generales y relacionados del concepto de civilización que aquí rechazamos; por un lado la idea normativa de civilización en tanto grado superior de desarrollo cultural cuya cúspide alegadamente es la "Civilización Occidental" (como en la conocida oposición de "Civilización" contra "Barbarie" que tan influyente ha sido en los imaginarios occidentalistas); y por 
otro lado el concepto geo-histórico de civilización (común en las humanidades, antropología e historia) como un continente humano de cultura que divide las geografías y poblaciones humanas como campos civilizacionales distintos y excluyentes. Ambas nociones de civilización son pilares ideológicos de lo que llamamos Civilización Occidental Capitalista. El primero como categoría clave del episteme moderno/ colonial que construye "Occidente" como espacio histórico-cultural de superioridad ética, política, epistémica, económica, étnico-racial y estéticocultural al resto del mundo y por ende su racionalidad de vida como el fin último de la historia humana. El segundo, fundamento de nociones esencialistas y hasta fundamentalistas de acuerdo a las cuales las culturas son compartimientos delineados de vida histórica que sirven de base para tipologías étnicoraciales que dividen la humanidad en segmentos en base a tipologías tales como Huntington en su libro El Choque de Civilizaciones. ${ }^{6}$

Al contrario, aquí usamos el concepto de civilización occidental capitalista para referirnos a las lógicas dominantes de economía, gobierno, conocimiento, estética, y subjetividad que surgen y se mantienen a partir de la emergencia del patrón de poder moderno/ colonial imperante en los procesos de globalización que emergen en el largo siglo XVI. En este registro, la civilización occidental capitalista significa una lógica civilizacional (es decir, un paradigma de vida) regido por la búsqueda desmedida de ganancia, relaciones mercantiles de competencia, formas de gobierno que separa jerárquicamente gobernantes y gobernados, y valorizaciones estético-culturales y epistémicas que afirman la superioridad de los sujetos y culturas Europeas y Eurodescendientes sobre el resto de la humanidad. En esta definición la civilización occidental capitalista denota una serie de discursos y prácticas culturales y formas de subjetividad que resultan fundamentales para la configuración y reproducción del patrón de poder moderno/colonial que denominamos colonialidad del poder.

Lo que llamamos civilización occidental se refiere a las lógicas culturales y formas de subjetividad (identidad, conocimiento, psicología) hegemónicas y dominantes en el sistema-mundo moderno/colonial capitalista. ${ }^{7}$
A la vez, hay un elemento ideológico en la idea de civilización occidental en la medida que pretenda ser una forma cultural abarcadora y excluyente de otras, aun en su misma orbita histórica principal. Es decir, los discursos, practicas, y formas de subjetividad de corte occidental siempre han co-existido con otras formas culturales, aun en los espacios considerados claramente occidentales como el continente Europeo y los Estados Unidos. Por ende, es importante reconocer por un lado la hibridez y la inter-culturalidad que constituye cualquier escenario histórico-cultural (incluyendo el “occidental"); y por otro lado, el carácter constitutivo de las modernidades (y no-modernidades) coloniales y periféricas de los modos de economía, gobierno, ética, estética, conocimiento, cultura, y subjetividad de la civilización occidental moderna; para entender y valorizar las luchas y acciones colectivas de los subalternos en las gestas históricas en aras de democracia, igualdad, des/colonialidad y liberación. En otras palabras, entendemos el poder y la cultura como procesos de relación social en donde las lógicas de ganancia desmedida, competencia, fragmentación, alienación, y dominación (étnico-racial, epistémica, cultural, política, económica) de la civilización occidental capitalista, siempre han sido desafiadas y parcialmente remplazadas por otras lógicas fundamentadas en principios como la reciprocidad, solidaridad, horizontalidad, y comunitarismo que implican proyectos alternos y alternativos de vida, en este sentido de civilización.

Cerramos esta parte retomando el planteamiento de Cesaire con el que abrimos el artículo. Nuestro argumento principal en esta monografía es que la crisis actual tiene las características de ser la más profunda y definitiva debido a que trastoca todas las aristas, todos los procesos fundamentales de la modernidad capitalista y su patrón de poder moderno/colonial. Es por esa razón que la caracterizamos como una crisis de la civilización occidental capitalista en su conjunto, y por ende declaramos con Cesaire que marca la decadencia de dicha matriz societal. Antes de elaborar y demostrar mínimamente dicho argumento necesitamos tanto una mirada histórica como una problematización de lo que han sido los procesos de crisis del capitalismo histórico. ${ }^{8}$ 


\section{Crisis Recurrentes y Crecientes del Capitalismo Histórico}

Los procesos político-económicos del patrón del poder, que sobre todo en sus aspectos de economía-política y geo-política denominamos capitalismo histórico, han sido azotados por crisis globales al menos desde la primera globalización propiamente dicha en el siglo XIX. Tanto las causas como la temporalidad de dichas crisis son asuntos ampliamente debatidos. Desde perspectivas radicales y marxistas uno de los argumentos más comunes es a partir del economista ruso Kondratieff quien planeo a principios del siglo XX un análisis de los ciclos de larga duración del capitalismo en base a ciclos que duran alrededor de 50 años divididos en un periodo ascendente de crecimiento (Fase A) y un periodo descendiente de crisis (Fase B). Kondratieff fundamento sus ciclos en el comportamiento de los precios y por eso ha sido criticado no solo como economicista sino también por tener una reducida lógica macroeconómica. ${ }^{9}$ Sin embargo, Ernest Mandel y David Gordon elaboraron argumentos de corte socio-histórico donde los ciclos de aproximadamente 50 años por un lado se nutren de una dinámica macroeconómica más compleja (teniendo en cuenta factores como la organización del trabajo, el cambio técnico, la tasa de ganancias, y los niveles de actividad económica y demanda efectiva), y por otro lado se fundamenta en análisis socio-histórico de fenómenos como luchas de clase, acciones colectivas, guerras y revoluciones. Nuestro análisis es afín a los planteamientos de Gordon y Mandel, como también de los argumentos de la escuela regulacionista y Giovanni Arrighi de que las crisis cíclicas del capitalismo son productos de complejas constelaciones de factores que no solo incluyen las dinámicas económicas sino también determinantes de tipo político como son las luchas sociales, las políticas estatales y las relaciones geo-políticas entre estados y otros actores transnacionales (como la Organización Mundial de Comercio). ${ }^{10}$ Esto nos lleva a periodizar el capitalismo histórico tanto en base a periodos de hegemonía mundial de potencias imperiales-Holanda en el siglo XVII, Gran Bretaña en el siglo XIX, y Estados Unidos a mediados del siglo XX; como también de patrones históricos de acumulación-del mercantilismo Holandés en el siglo XVII, al imperialismo de libre comercio del siglo XIX, hasta el giro del Keynesianismo Global como respuesta a la crisis de los 1920s-30s al Neoliberalismo Global y sus crisis a finales del siglo XX y principios del XXI. No podemos desarrollar esta periodización en este artículo, pero va a informar nuestro análisis de la crisis tanto en sus dimensiones económicas como políticas y culturales.

Los debates en relación a las causas de las crisis recurrentes del capitalismo son directamente pertinentes para la explicación de la crisis actual. Como vimos rápidamente, al menos desde el marxismo de la segunda internacional ha habido debate vivo sobre la causas de las crisis del capitalismo y que implican estas para la teoría y praxis política. Un conocido debate es entre el atribuir las crisis al subconsumo o la carecía de demanda agregada en la economía (Rosa Luxemburgo), en contraste a verla como una ausencia de inversión productiva debido a la tendencia a la caída en la tasa de ganancias (Bukharin), dilema que está presente hasta el día de hoy. Abordaremos este debate más adelante en el contexto de discutir las dinámicas de la crisis actual. 
Para entender la crisis actual es necesario destacar dos atributos generales de las crisis recurrentes del capitalismo histórico; por un lado su carácter cíclico y por otro lado el que su magnitud y profundidad es cada vez mayor. Si partimos de mediados del siglo XIX podemos identificar crisis cíclicas desde la crisis de 1870s, la depresión de los 1930s, y la crisis presente que emergió en los 1970s. Pero además de ser recurrentes dichas crisis son cada vez mayores tanto en su escala espacial y profundidad de efectos, como en las aéreas de la vida social que afectan. A este carácter creciente de las crisis del capitalismo histórico lo caracterizamos como una tendencia secular a ser cada vez mayor y por ende a desafiar la capacidad del sistemamundo moderno/colonial capitalista de recuperarse y reestructurarse.

\section{Raíces y Temporalidad de la Crisis Actual}

Hay diferentes modos de entender y explicar la crisis presente. La narrativa dominante en los medios de comunicación masiva, los centros de poder político y económico, y en el mundo académico, es verla como una crisis financiera, de corto plazo y en cada país, que se puede solucionar relativamente rápido a partir de megainyecciones de fondos de parte del estado con el fin de restablecer las condiciones de rentabilidad del capital y por ende la salud de la economía en general. Este tipo de análisis es producto de un sentido común que combina las herramientas de análisis de la economía neoclásica que asume el capitalismo como única alternativa de resolver la vida material (producción, distribución, y consumo), con miradas a corto plazo y a escalas simples (locales y nacionales).

En contraste, los análisis marxistas y radicales de la crisis actual la entienden como un problema más fundamental, de larga duración, y de carácter global, pero aun tendiendo a enfocar en lo económico. Aun si solo se ve la crisis en su dimensión económica, su temporalidad es mucho mayor que el debacle financiero y de bienes raíces de los Estados Unidos en el 2008. Lo mismo se puede argumentar de otras crisis financieras de tipo similar, como las que ocurrieron en México en los 1980s, en Asia del Este en los 1990s y Argentina en el 2001, y que aquí las analizamos como sintomáticas de problemas mayores relacionados a la financiarización de patrones de acumulación no solo en escenarios nacionales sino también a escala mundial. Pero antes de entrar en una discusión más detallada de las dinámicas de la crisis presente, es imperativo historizarla. 
Si usamos la periodización elaborada tanto por Arrighi como por Wallerstein, veremos que entre los 1870s y el momento presente han ocurrido por un lado tres crisis económicas mundiales $(1870,1930$ s, 1970s hasta ahora) en conjunción con tres olas de movimientos antisistémicos; y por otro lado la caída de dos imperios hegemónicos (primero el Británico y después el Estadounidense) acompañadas por una cantidad sin precedentes de guerras, revoluciones, y gestas por la descolonización. Si concentramos en el siglo XX y lo que va del XXI, resalta primero el periodo de guerras, revoluciones, movimientos mundiales por reivindicaciones sociales y nacionales que corrió aproximadamente entre 1914-1945. Algunos de los hitos de esta era fueron la revolución soviética y la revolución Mexicana, dos grandes guerras entre las potencias europeas, la gran depresión de 1930s, una suerte de globalización de movimientos comunistas y socialistas (junto con anarco-sindicalistas en el caso de la guerra civil española), la emergencia de movimientos por la autodeterminación nacional, y el surgimiento del Pan-Africanismo como una fuerza política y cultural en escenarios mundiales.

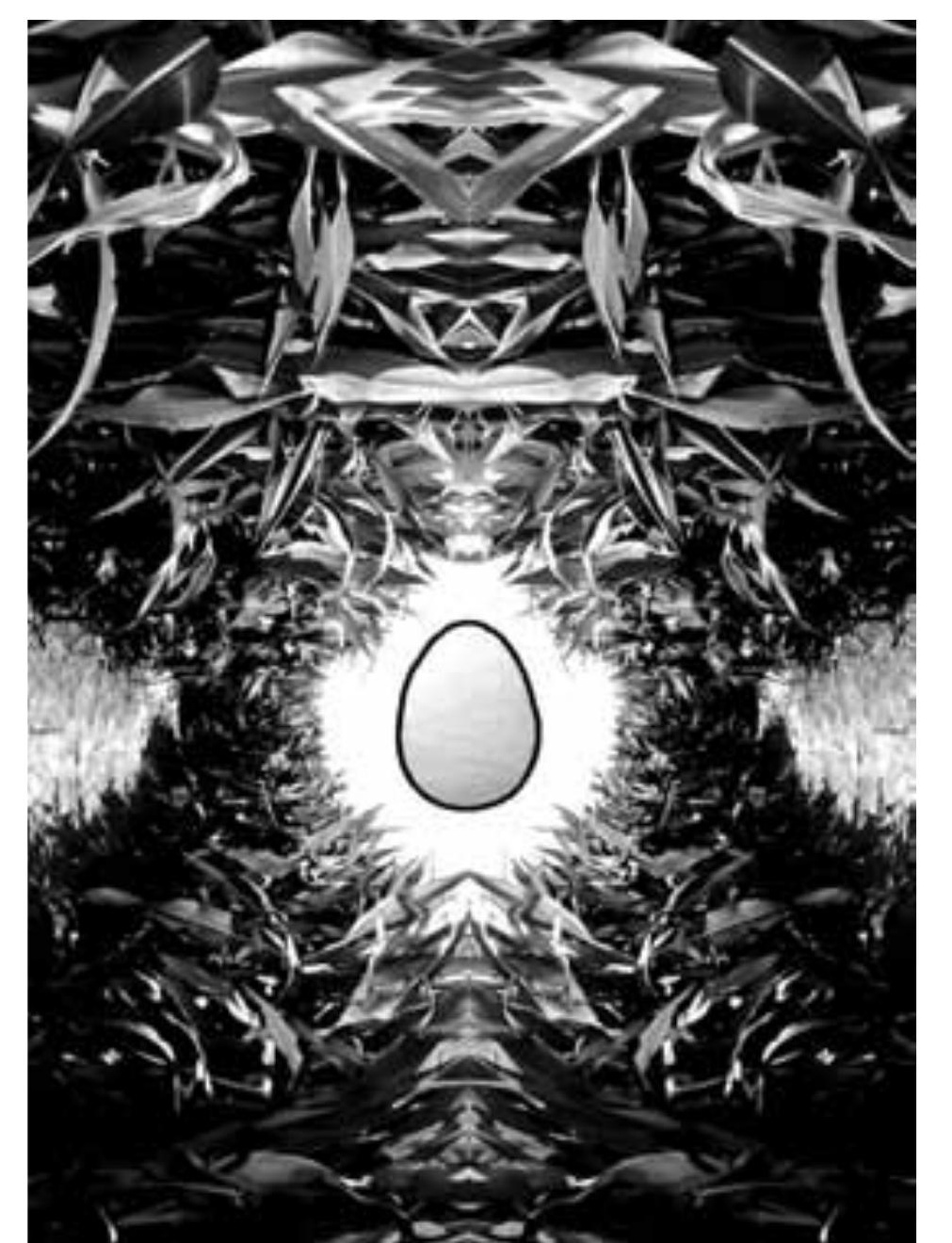

La crisis económica de los 1930s se resolvió por mediación de una serie de procesos entre los que se destaca la adopción de las políticas económicas aconsejadas por el economista Británico Keynes, que perseguían estimular la economía a partir de políticas fiscales de inversión estatal y emisión de dinero, para promover actividad económica y elevar el nivel de empleo con el fin producir la demanda necesaria para resolver la crisis de realización (o venta) de productos, que según su análisis era la causa principal de la crisis. El keynesianismo que impero desde la crisis mundial anterior no fue norma sino excepción en el modus operandi del capitalismo histórico. El estado interventor a favor del desarrollo económico (en América Latina el estado desarrollista y populista), el estado benefactor en aras de empleo pleno y consumo colectivo (sobre todo en los países del centro), fue producto tanto de estrategias para lidiar con la crisis económica, como de las luchas históricas de los ciudadanos y sobre todo de las clases subalternas demandando extensión del sufragio a través de derechos sociales y políticos. Las dimensiones políticas de aquella crisis variaron desde el surgimiento del Fascismo como forma de gobierno y fuerza continental en Europa, el Nuevo Trato en los Estados Unidos, la oficialización de partidos socialdemócratas y sus sindicatos en Europa, y la división del mundo entre el "Bloque Occidental" (básicamente Europa y los Estados Unidos) y el "Bloque Soviético" de acuerdo a los términos iniciales de la guerra fría.

Otra ola de movimientos sociales comenzó a mediados de los 1950s-tres cuyos referentes claves fueron: 1) la primera reunión de la conferencia de países no-alineados en Bandung, Indonesia en 1955; 2) el movimiento de liberación negra en los Estados Unidos (1956-1970s) y; 3) la revolución cubana (1959); y que tuvo se termino inmediato en los 1970s. El clímax de esta coyuntura histórico-mundial que se ha catalogado de "revolución en el sistema-mundo moderno", "1 fue en enero 1968 con la ofensiva de Tet dirigida por Viet-Nam del Norte, la huelga general en Francia de obreros y estudiantes, y el escalamiento de una constelación de movimientos que incluyeron luchas anti-guerra, de estudiantes y "minorías raciales" en los Estados Unidos; fueron detonantes fundamentales de lo que entendemos como crisis sistémica del patrón de poder. 
El conjunto de ideologías, discursos, políticas de gobierno, y formas de explotación del trabajo y acumulación de capital, que denominamos como neoliberalismo son producto de un conjunto de estrategias económicas, políticas, e ideológicas para reestructurar las condiciones de rentabilidad del capital y poder occidental como respuesta a una severa crisis de acumulación y legitimidad en el sistema-mundo moderno/colonial capitalista. Los procesos de globalización que describimos como neoliberales también son en gran medida estrategias de restructuración de las condiciones de rentabilidad del capital a través de la elaboración de un nuevo paradigma de desarrollo capitalista en base a una revitalización y redefinición de las doctrinas del liberalismo económico que imperaron a finales del siglo XIX, la era del imperialismo de comercio libre bajo hegemonía Británica. La emergencia de la doctrina y las políticas neoliberales a finales de la década de los 1970-dos marcadores siendo las políticas económicas de los "Chicago Boys" en el Chile de la dictadura de Pinochet y la crisis fiscal de la ciudad de Nueva York-marco una nueva era que contrarrestó parcialmente la crisis tanto económica como política: abriendo mercados, facilitando mayor explotación del trabajo, redefiniendo el rol del estado más claramente a favor del capital, y articulado proyectos ideológicos imperiales para occidente y el capital global.

A la misma vez, el capitalismo neoliberal ha sido confrontado por movimientos y movilizaciones a través del mundo desde rebeliones populares espontaneas como el Caracazo en el 1989 y nuevas luchas armadas como el levantamiento Zapatista de 1994 (que conscientemente coincidió con la firma del tratado de libre comercio de América del Norte-NAFTA), hasta movimientos sociales de desocupados (como los Piqueteros en Argentina), campesinos (como los Sin Tierra en Brasil) y de la nueva clase obrera (como Conserjes por la Justicia de trabajadores inmigrantes Latinos en Los Ángeles, California). Dos ejemplos principales de como confluyen y entran en coalición estos movimientos son las demostraciones masivas y militantes contra organizaciones del capital transnacional comenzando por las movilizaciones contra la Organización Mundial de Comercio en Seattle, Washington, EEUU en Diciembre de 1999 y los procesos de Foro Social a partir del Foro Social Mundial en Porto Alegre, Brasil en Enero de 2001, como veremos más adelante. Ahora regresamos a explorar la economía-política de la crisis presente.

\section{Perspectivas de Economía-Política de la Crisis Presente}

Hay un importante debate en cuanto a la economía política de la crisis actual. Aquí concentraremos en la teoría marxistas y radicales que son las que intentan formular explicaciones de fondo. Planteamos de entrada una postura contra la reducción tanto de lo económico a lo financiero como también critica de la reducción de la crisis a sus dimensiones de economía política. A la misma vez, reconocemos el significado fundamental de la economía política del capitalismo para entender el carácter, dinámica, y profundidad de la crisis. 
A pesar de las diferencias hay tres elementos claves que recuperamos de las teorías marxistas y radicales de la crisis: que son sistémicas, que tienen una recurrencia cíclica, y que son de carácter creciente o secular. Las crisis del capitalismo no son simples fluctuaciones en los ciclos de negocio sino producto de sus contradicciones políticas y económicas y de intentos de restructuración del patrón de poder. En el sentido estricto económico son crisis de rentabilidad del capital (o sea de ganancias) lo cual implica disminución en los niveles de inversión acompañados por crecimiento del capital financiero, destrucciones masivas de capital, desempleo masivo, marginalidad y hambre para las masas trabajadoras, los sectores populares y los campesinados. Caracterizamos su aspecto económico como una crisis de acumulación de capital a escala mundial que comenzó a principios de los 1970s, cuyos síntomas más patentes fueron la subida de los precios del petróleo en 1973, el déficit fiscal del estado imperial estadounidense a partir de la guerra de Viet-Nam, y la combinación sin precedentes de inflación y estancamiento que se llamo stagflation. Este momento marco una tendencia de: disminución tasa de ganancias, desempleo estructural, reducción de salarios reales, empobrecimiento creciente y masificación de la marginalidad social. Este momento marco una tendencia de larga duración a bajar la tasa de ganancias, desempleo estructural, reducción de salarios reales, erosión de la forma salarial trabajo (trabajo excedente/vidas desechables), nueva esclavitud y nuevas servidumbres, empobrecimiento creciente y masificación de la marginalidad social dinámica que persiste con sus altas y bajas hasta hoy día. ${ }^{12}$

En contraste a los análisis de los economistas neoclásicos y keynesianos, los marxistas y radicales no ven la situación actual como una recesión de corta duración sino como expresión de una condición persistente de problemas económicos que comenzó en la década de los 1970s. Las diferencias son en las causas principales, la dinámica de la crisis, el rol del estado y los actores sociales, sus implicaciones políticas, y los proyectos y horizontes de futuro. Visto desde al ángulo macro-económico hay cinco explicaciones generales encontienda en el campo de la economía-política marxista y radical:

1) Un análisis marxista clásico de la crisis de acumulación de capital explicada en base a la tendencia a la caída en la tasa de ganancias provocada por un aumento en la composición orgánica de capital-es decir menos “trabajo vivo" realizando producción y mayor "trabajo muerto" objetivado en medios de producción. ${ }^{13}$ A pesar de las "contratendencias" (por ejemplo por sobre-explotación del trabajo o apertura de mercados), la tendencia mayor sigue siendo a la caída en la tasa de ganancias, y esto se afirma en situaciones de crisis cuando cae el capital productivo y asciende el capital financiero. ${ }^{14}$

2) Un análisis "subconsumista" de acuerdo al cual la causa principal de la crisis es la carencia de "demanda efectiva" que provoca una "crisis de realización" de las mercancías que tiene como consecuencia un descenso del nivel de actividad económica y por ende un circulo vicioso de escasez de inversión, producción, y consumo. ${ }^{15}$ Dicha dinámica dirige la actividad económica a un exceso de especulación financiera sin necesariamente intentarlo.

3) Una explicación en base a un exceso de producción en relación a la capacidad de rentabilidad del capital, lo que se describe como una crisis de sobre-acumulación que tiene como resultado destrucción de capitales (desde planta física y espacio urbano hasta mercancías) con la consecuente baja en inversión productiva, trabajo, y consumo. ${ }^{16}$ 
4) Una interpretación de la crisis en base al estancamiento estructural en el nivel de salarios a partir de la incepción del neoliberalismo y la enorme ofensiva de la burguesía contra la clase trabajadora que esto represento, partiendo de la premisa que su eje central es los Estados Unidos. De acuerdo a este argumento la causa económica principal de la crisis es la carencia de aumento en los salarios reales en los EEUU a partir de los 1970s, esto asociado a la emergencia de un patrón de capitalismo financiero especulativo que provoco la crisis financiera reciente. ${ }^{17}$

5) Un análisis multifactorial de la crisis entendida como resultado de una diversidad de fuentes de desequilibrio y disfuncionalidad que potencialmente existen en varias dimensiones de la economía política del capitalismo incluyendo: sobre-acumulación de capital, falta de demanda, aumentos salariales relativos a las ganancias, desproporciones y destiempo en varios renglones de la economía entre los cuales se cuentan: temporalidad del cambio tecnológico ligado a la oferta y demanda de medios de producción, carencia de correspondencia entre cadenas de mercancías, lugares de producción y patrones de consumo, y erosión relativa de mercados sobre todo de recursos naturales y materias primas. ${ }^{18}$ Aquí plantearemos una versión de esta vertiente que entiende la crisis como resultado de una multiplicidad de contradicciones en el sistema-mundo moderno/ colonial capitalista, como veremos más adelante.

Algunos de los análisis hechos por marxistas occidentales como Robert Brenner y Alex Callinicos,${ }^{19}$ parten de perspectivas Américo-Eurocéntricas que conciben los problemas económicos y las guerras de occidente como fuerzas motrices de la crisis global. Siguiendo una lógica similar el economista marxista francés Gerard Dumenil argumenta que las causas principales de la crisis actual "son los desequilibrios de la trayectoria económica de Estados Unidos, la aceleración de mecanismos financieros basados en un endeudamiento "insostenible” y el financiamiento de los desequilibrios de la primera potencia por parte del resto del mundo". ${ }^{20}$

En contraste, analistas de la modernidad capitalista en como sistema-mundo, entre ellos Samir Amin, Giovanni Arrighi, e Immanuel Wallerstein, entienden la crisis como un fenómeno global en su conjunto a la vez que tienden a conjugar las dinámicas económicas con fenómenos geo-políticos (imperialismo, hegemonía mundial, guerras) y luchas históricas (movilizaciones, movimientos antisistémicos, revoluciones). A partir de esta óptica Amin arguye que el "sistema capitalista entro en crisis a partir del 1968 (crisis política y erosión de la legitimidad de sus discursos) y de 1971 (abandono de la convertibilidad en oro del dólar).” A esto añade que la "crisis actual no es más que una etapa (ciertamente nueva) de esta larga crisis, que se remonta por tanto al comienzo de los años setenta. Esta larga crisis se produce por un marcado debilitamiento de las tasas de crecimiento y de inversión que no han vuelto a alcanzar nunca (e insisto en ese "nunca") los niveles que habían alcanzado en la post-guerra." También analiza la erosión relativa de las fuentes naturales de materias primas y productos (como el agua, el oro, el petróleo), el aumento de la "acumulación por expropación" (expropiación de comunidades de sus territorios y de campesinos de sus tierras para crear nuevas fuentes de ganancia, recolonización de espacios urbanos para vivienda y negocios rentables para el capital), y el dominio del capital financiero como hitos de la crisis presente. Amin concluye que "Es necesario reunir todas las dimensiones de esta importante crisis sistémica en un 
análisis integrado" a la vez que formula los dilemas históricos y políticos de la crisis en una fórmula de "Socialismo o Fascismo" donde un factor decisivo será "como responderán al desafío los estados y los pueblos del Sur”. Sin negar sus virtudes, el análisis de Amin se queda en los límites de la economía política a la vez que la alternativa política que plantea reduce la riqueza de las luchas presentes a una formula de socialismo tercermundista.

Uno de los análisis más complejos y de mayor riqueza de la economía política de la crisis del sistema-mundo capitalista es el de Giovanni Arrighi quien a pesar de fallecer en el momento mismo del debacle financiero de 2008 contribuyo de forma significativa a su comprensión. Arrighi al igual que Wallerstein, ven la crisis de acumulación en relación a la crisis de hegemonía del imperio estadounidense, y ambos realizan análisis magistrales de los avatares y contradicciones económicas y geo-políticas del periodo actual. Aquí queremos destacar tres elementos del análisis de Arrighi: primero, su argumento de que en cada ciclo sistémico de acumulación emerge como dominante el capital financiero una vez el capital productivo entra en una crisis de ganancias; ${ }^{21}$ segundo que las crisis sistémicas implican situaciones de caos en el capitalismo histórico tanto en las condiciones económicas como en la estabilidad política lo que quiere decir intensidad de guerras, olas de movimientos antisistémicos, y perdida de hegemonía mundial, todo lo cual ha desembocado en procesos de reconfiguración del sistema en su conjunto a partir de la agencia histórica de nuevos poderes hegemónicos (Holanda en el siglo XVII, Gran Bretaña en el siglo XIX, y Estados Unidos en el Siglo XX); tercero, que tanto los requisitos de acumulación de capital (la lógica económica) como de hegemonía imperial (la lógica geo-política) de reproducción del sistema son cada vez mayores y por ende en cada crisis se hace más difícil superar el caos y reconfigurar las condiciones de rentabilidad y hegemonía. Esto último implica que "cada centro emergente de su serie es de mayor escala y ámbito territorial que sus precedentes" y que "la expansión del capitalismo mundial se ha basado en la formación de organizaciones capitalistas dirigentes cada vez más poderosas". ${ }^{22}$ En general, estamos de acuerdo con estos tres argumentos de Arrighi, aunque los consideramos insuficientes tanto para entender la crisis como para crear alternativas. El argumento del carácter creciente de las crisis y por ende de mayor dificultad en la recuperación y restructuración, que ya había sido planteado aunque solo de manera incipiente en Marx, es clave tanto para caracterizar la condición actual como para elaborar alternativas de futuro como veremos más adelante.

Una de las interpretaciones más influyentes del capitalismo contemporáneo en general y de la crisis presente en particular es la de David Harvey, quien es sus últimos libros ha sido influenciado por la analítica de Arrighi. Para nuestros propósitos en este articulo resaltaremos tres de sus planteamientos principales: primero, el argumento de la centralidad de la acumulación por desposesión como estrategia clave en el paradigma neoliberal de globalización capitalista; segundo, la importancia del espacio y la territorialidad en los procesos tanto de acumulación de capital como de poder imperial; y tercero, la concatenación de una pluralidad de procesos en la causación de la crisis actual. 

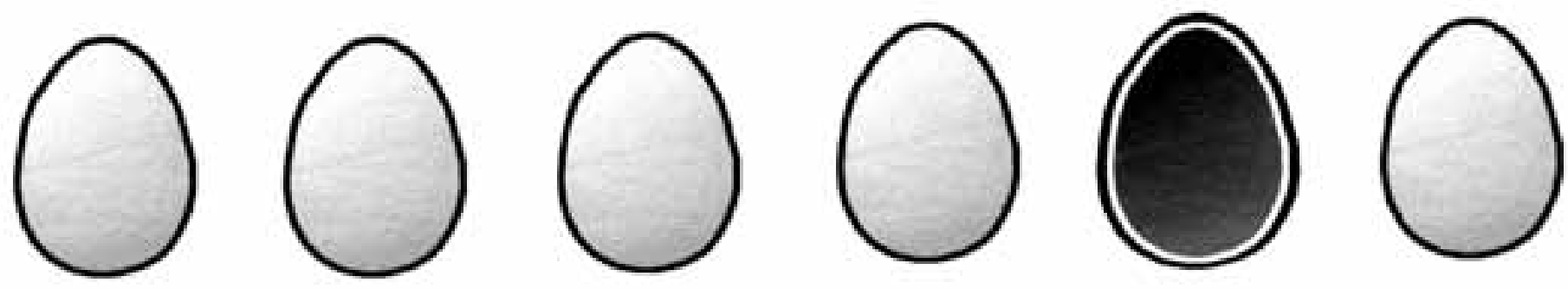

El concepto de "acumulación por desposesión" se deriva del de "acumulación primitiva de capital" que postula Marx para explicar el surgimiento del capitalismo como modo de producción dominante a través de procesos de mercantilización de la tierra y creación de fuerza de trabajo subyugada al capital por medio de expropiación de tierras comunes y pequeña propiedad campesina. Aunque ahora dicho concepto suelte asociarse a Harvey, su lógica tiene una historia más antigua en las teorías latinoamericanas de la dependencia, para analizar los procesos de expropiación de tierras, creación de fuerzas de trabajo, y apropiación de recursos naturales que han caracterizado toda la historia del capitalismo sobre todo en las periferias. ${ }^{23} \mathrm{La}$ contribución de Harvey es vincular la acumulación por desposesión al capitalismo en su fase neoliberal y sus crisis. La siguiente cita resume sus argumentos con claridad y detalle: "El Capital Financiero y la acumulación por desposesión han cobrado históricamente muchas formas diferentes, incluida la conversión de distintos tipos de derechos de propiedad (comunal, colectiva, estatal, etc.) en derechos de propiedad exclusivos; los procesos coloniales, semicoloniales, neocoloniales e imperiales de apropiación de activos y recursos naturales; y la supresión de alternativas al uso capitalista de los recursos humanos y naturales. Aunque en el modus operandi de estos procesos haya habido mucho de contingente y azaroso, es preciso afirmar que el capital financiero y el sistema de crédito han sido importantes palancas de desposesión, mientras que los Estados, con su monopolio de la violencia y su definición de la legalidad, han sido protagonistas decisivos." ${ }^{24}$ Desde esta perspectiva, la acumulación por desposesión articula una serie de vectores del capitalismo neoliberal, es decir, significa un proceso que liga el ascenso del capital financiero con modos contemporáneos de apropiación de recursos naturales, expropiación de la tierra, sobre-explotación del combinado de estado, imperio, y capital. Esta lógica también articula los análisis de Harvey sobre la apropiación del espacio como estrategia capitalista de aminorar crisis y producir ganancias, con su economía política del nuevo imperialismo estadounidense. En este sentido, un componente importante de la crisis actual es la erosión de la opción de crear fuentes de ganancia a través de “arreglos espaciales" por medio de actividades como la construcción de ambiente urbano y la apertura de mercados exteriores. Otra contradicción clave, es entre la lógica de acumulación de capital y la lógica territorial del poder imperial que tiende a desviar recursos a favor de lo militar y en contra de la recuperación económica, lo que se profundiza en tiempos de crisis. Aquí se revelan aspectos significativos de la crisis a la vez que tanto su análisis del imperialismo y de los significados sociohistóricos del espacio (sobre todo la cuestión urbana), como las alternativas políticas que formula, son planteados desde una óptica estrictamente marxista donde priman las clases sociales en detrimento de otras formas de dominación y lucha. 
El tercer elemento a discutir en relación a Harvey es su análisis de la crisis actual como proceso de fuentes diversas que es determinado por mediaciones múltiples. Harvey realiza un detallado análisis de como la crisis financiera del 2008 en los Estados Unidos, a la que califica como "madre de todas las crisis", la culminación de una serie de crisis financieras y comerciales particulares entre las cuales destaca la de el Este de Asia en 1997, Rusia en 1998, y Argentina en el 2001, y que ahora avanza cual "cascada de una esfera a otra y de una localización geográfica a otra." ${ }^{25}$ También traza la crisis actual a los 1970s presentando una trayectoria desde la elevación de los precios del petróleo por el cartel de la OPEC en 1973 en conjunción con las crisis fiscales (el ejemplo clave el de la ciudad de Nueva York) estatales y el "crash" de los mercados globales de propiedad en la misma era; hasta la conversión de la deuda en un problema mayor a partir de la circulación de los petrodólares a través de préstamos desmedidos otorgados principalmente por el gran capital financiero a países dependientes que no ostentan el poder occidental que terminaron crónicamente endeudados, todo esto desembocando en la crisis del dólar y las políticas de ajuste estructural administradas por el Fondo Monetario Internacional. Harvey define las crisis como "una condición en la cual la producción y reinversión del excedente son bloqueados" (y por ende) "el crecimiento para y aparece como una sobre-acumulación de capital que es devaluado o destruido". ${ }^{26}$ En la crisis actual esto ha implicado la disminución e informalización del trabajo junto a la emergencia de un patrón de ganancia donde prima especulación financiera que no está sustentada en producción de riqueza, por lo cual tarde o temprano hubo de llegar a sus límites. Dicha dinámica es catalizada por una serie de "barreras potenciales a la acumulación" desde problemas y conflictos entre capital y trabajo, precariedad de demanda y mercados, exacerbación de competencia económica y geo-política entre poderes dominantes, hasta "crisis de proporcionalidad" entre distintas fases de producción y circulación del capital. En fin, el análisis de Harvey historiza y complejiza las dimensiones de economía política de la crisis actual, pero su óptica no avanza mucho mas de las lógicas económicas y geo-políticas, lo que es afín con su reduccionismo de clase al plantear alternativas de proyecto histórico y por eso su propuesta política no articula una visión más allá de las propuestas de redistribución de riqueza y poder del socialismo del siglo XX.

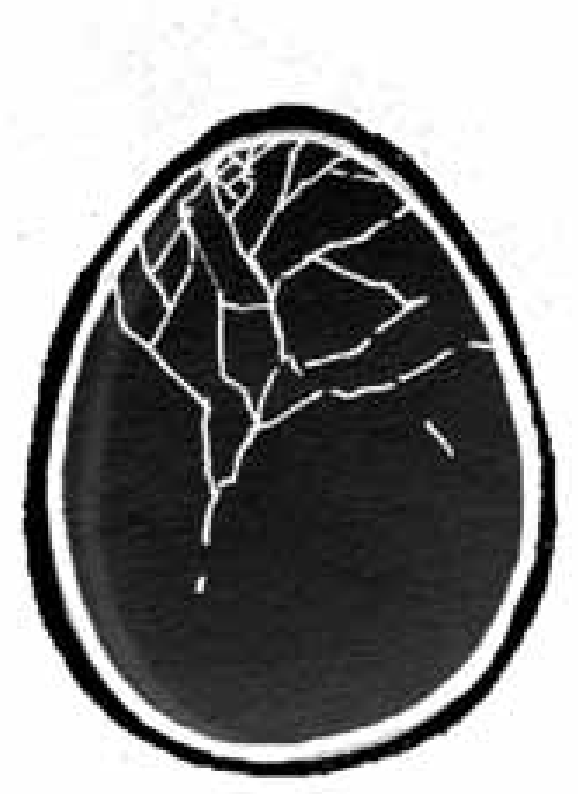

En general coincidimos con el tipo de interpretación que realiza Harvey de la crisis actual en la cual se analizan una diversidad de fuentes que causan la caída en la tasa de ganancias y los niveles de actividad económica lo cual tiene como consecuencia un capitalismo de casino, o sea un patrón de acumulación sustanciado en finanzas y especulación. Sin embargo, nuestra interpretación de las crisis cíclicas y crecientes de la modernidad capitalista, y particularmente de la que encaramos ahora, transciende los instrumentos de análisis de la economía política. Como bien dice el intelectual cubano Fernando Martínez Heredia, hay que superar el economicismo y "colocar la crítica revolucionaria en el plano de la totalidad del sistema". ${ }^{27}$ 


\section{Crisis del Patrón de Poder Moderno/Colonial \& Critica de la Economía Política}

Concebir la condición presente como una crisis del patrón de poder en su conjunto ${ }^{28}$ supone un análisis más complejo de las formas del capitalismo en su fase de globalización neoliberal, como también una crítica de la economía política en tanto discurso principal para entender la crisis y crear alternativas colectivamente. En esa vertiente, enfatizaremos algunos rasgos del capitalismo contemporáneo a partir de la caracterización que hace Aníbal Quijano de la crisis actual, lo que también implica una crítica de la economía política, si esta se asume como una analítica de procesos político-económicos desarticulados de otros fenómenos fundamentales en la vida social (culturales, éticos, epistémicos, ideológicos, etc.). Nuestra crítica de la economía política, también envuelve transcender el "capitalocentrismo", o sea mirar la modernidad capitalista y sus múltiples dimensiones mayormente a través del prisma de la lógica del capital, junto con la tendencia a reducir lo económico (la producción y reproducción de la vida material) como derivado de la dinámica capitalista. ${ }^{29}$

Uno de los pilares principales del análisis que hace Aníbal Quijano de la crisis actual del patrón de poder es su caracterización y diagnostico de las formas presentes de organización y explotación del trabajo en relación a la nueva revolución tecnológica y a la tendencia secular a la caída de la tasa de ganancias. Quijano argumenta que el capital ha logrado una capacidad productiva tal que necesita mucho menos trabajo vivo en relación a la fuerza de trabajo existente en el planeta lo que tiene como consecuencia un patrón constante de desempleo estructural que es una de las causas de la crisis de rentabilidad del capital (debido a la carencia relativa de producción de riqueza), a la vez que es una de las razones principales que explica la emergencia de nuevas formas de servidumbre y esclavitud, como también de la creciente precarización y flexibilización del trabajo asalariado junto con la informalización del trabajo social en el capitalismo actual. Dicha dinámica también apunta hacia el desarrollo de un patrón de acumulación basado en el capital financiero, una especie de capitalismo de casino donde el sector financiero ya no es coyuntural sino estructural. La financiarización de las instancias dominantes de la economía mundial converge con la nueva revolución tecnológica que facilita la creación de formas virtuales de dinero y mercados de especulación sin sustento productivo que desembocan en nuevos tipos de crisis que se expresan como "gigantescos fraudes financieros". Quijano argumenta que, "el capitalismo colonial/moderno ya no produce, ni producirá, más empleo, ni más salario, salvo precarizado y flexibilizado, ni más servicios públicos, ni más libertades civiles. Todo lo contrario. Por eso, la esclavitud y la servidumbre están en plena re-expansión, con su perversa ética social ahora explícita de nuevo, siempre al servicio del capitalismo, y por todo esto requiere el máximo control de la subjetividad y de la autoridad.”30 
En resumen, para Quijano la “crisis raigal” implica una reconfiguración del patrón de poder en todas sus aristas desde la explotación del trabajo y los procesos de acumulación de capital, hasta los regímenes políticos, las prácticas culturales, los modos de comunicación y conocimiento, y las formas de subjetividad. La crisis realza los elementos despóticos del patrón de poder (tanto en los centros metropolitanos como en regiones y países subordinados) lo que conlleva a la erosión definitiva de las formas democráticas de la modernidad capitalista y a una "reconcentración del poder" y "privatización del estado", todo lo que indica la emergencia de formas institucionales y culturas políticas de corte autoritario e incluso neofascista. A escala mundial estas reconfiguraciones del poder político se expresan en la constitución de lo que Quijano denomina bloque imperial global, para significar el accionar conjunto de instituciones del capital transnacional como el Fondo Monetario Internacional y la Organización Mundial de Comercio, con los estados metropolitanos y las corporaciones transnacionales. Dicho bloque imperial global dirigió a partir de la derrota histórica de los procesos revolucionarios a finales de los 1970s, un proceso de intensificación de la globalización del capitalismo con vocación de colonizar, mercantilizar y privatizar todas las aéreas de la vida incluyendo los espacios públicos, las producción intelectual, los recursos naturales básicos, y la corporalidad humana. Quijano postula tres procesos claves en dicho patrón de globalización: "una reconcentración mundial del control de la vida pública a escala global", "la reprivatización del control de la autoridad colectiva", y "la recolonización del control de los recursos de producción y del capital en su conjunto" ${ }^{31}$ Esto a su vez se asocia a la profundización de las resistencias y provoca crisis de legitimidad y gobernabilidad que exacerban la situación de caos sistémico. ${ }^{32}$ Toda esta dinámica le otorga un nivel central a las luchas epistémicas (por sentidos, memorias, valorización de saberes y experiencias) que definen el carácter de la subjetividad y los horizontes de futuro. En esta vena, Quijano argumenta que "los deseos y necesidades de poder y de lucro de los controladores de este poder son, cada vez más, ilimitados y perversos. Todo recurso es, en ese sentido, instrumental para esos fines. Eso lleva a la destrucción de nuestra casa común, el planeta, y a matarnos entre nosotros"; y concluye que "de ese modo, en su fase actual este patrón de poder es el mayor peligro global” y que "el actual nuevo período implica el conflicto más profundo del capitalismo colonial/ moderno y nos coloca a todos en una auténtica encrucijada histórica." ${ }^{33}$

Esta valorización que hace Quijano de la era presente como crisis raigal del patrón de poder moderno/colonial, nos lleva a profundizar las distintas dimensiones de la crisis actual. ¿Cuáles son sus expresiones claves?, ¿qué hay de particular en esta crisis?, ¿cuáles son las posibilidades de restructuración de la modernidad capitalista y su patrón de poder? , ¿cuáles luchas surgen en este contexto?, ¿qué perspectivas de futuro se van construyendo en el camino? 


\section{Peculiaridades de la Crisis Actual}

Como ya hemos argumentado, las crisis del sistema-mundo moderno/colonial capitalista son recurrentes y crecientes. Como también hemos dicho, la crisis actual es la de mayor escala y profundidad que este sistema ha experimentado, y por eso se cuestiona la capacidad que pueda tener el sistema de revivir sus condiciones de rentabilidad y crecimiento. Varios de los analistas de la crisis actual la entienden como terminal dado que el capital en su fase de globalización neoliberal ya ha intentado colonizar todo el planeta, se acaban los espacios de mercado que abrir, el trabajo se ha precarizado, y la burbuja financiera ya estallo. Pero también hemos planteado que la crisis consiste en mucho más que sus dimensiones de economía política. De hecho, la peculiaridad principal de la crisis presente es que es real y efectivamente una crisis de la civilización occidental capitalista en sus múltiples dimensiones y lógicas diversas.

En lo que sigue de este articulo enfocaremos en cinco dimensiones adicionales de la crisis actual, las cuales denominaremos como crisis ecológica, epistémica, éticocultural, política, y de inter-subjetividades. Como bien plantea Francois Houtart, "lo que especifica la situación presente, si se compara con otras crisis financieras, en particular la del 1930, es la convergencia de varias crisis, de alimentación, energía, y climática, combinadas con las consecuencias sociales de pobreza, desempleo y migraciones." ${ }^{34}$ Más aun como argumenta Jorge Bernstein, "es muy difícil pronosticar el ritmo de la crisis en curso sobre todo porque no tiene precedentes en la historia del capitalismo; su carácter sistémico, su pluralidad (económica, energética, militar, institucional, tecnológica, ambiental, ideológica) y las interrelaciones entre sus diversas componentes le confieren un comportamiento errático, casi (pero no totalmente) impredecible." ${ }^{35}$ En esta exploración de las múltiples dimensiones de la crisis actual, comenzaremos por una de sus vertientes más peligrosas y con mayores implicaciones para la integridad del planeta y para la supervivencia misma de la vida misma, la cuestión ecológica.

\section{Crisis Ecológica, Alimentaria, Energética \& Nueva Política Ecológica}

Una de las dimensiones más críticas de la crisis civilizatoria actual es la ecológica. El llamado "cambio climático" es una especie de eufemismo para denominar el debacle ambiental causado por la acumulación en el tiempo de las injurias que el paradigma de desarrollo productivista y extractivista que prima en el capitalismo histórico ha causado en la ecología planetaria. La emisión indiscriminada de gases tóxicos alimentado por un modo de producción donde la naturaleza es vista como terreno para la apropiación y explotación y como fuente de ganancia, la revitalización de la minería a costa de la erosión y mercantilización de recursos vitales como el agua junto con la amenaza a las formas de vida ancestrales de comunidades indígenas, afrodescendientes y campesinas, y la insistencia de los poderes occidentales (bajo el recalcitrante liderato de los Estados Unidos) de continuar con esa racionalidad económica que cada vez destruye más el ambiente y pone en peligro la vida misma del planeta, componen lo que definimos como una severa crisis ecológica.

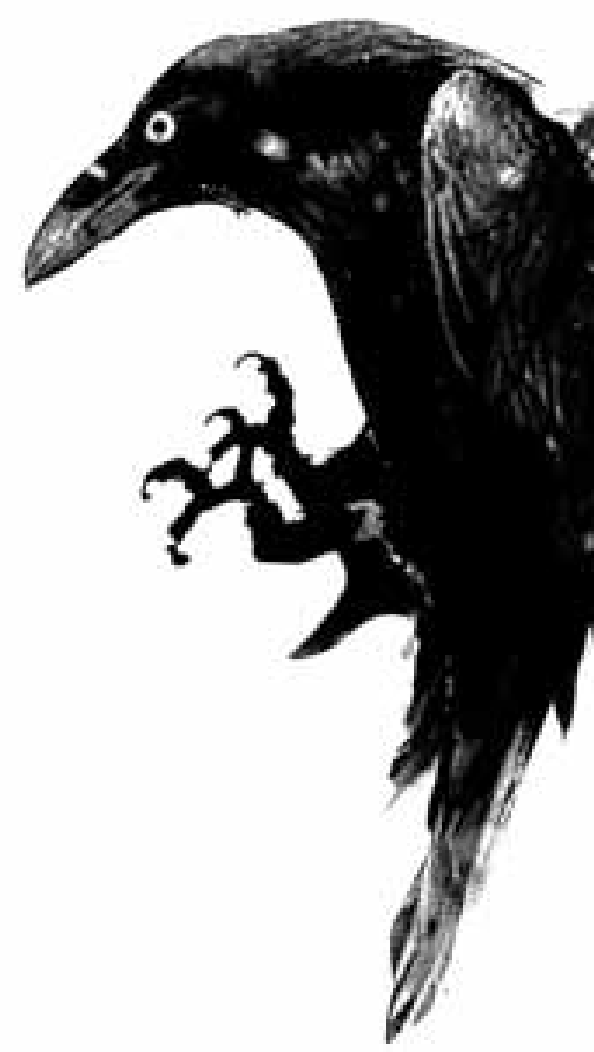


Uno de los síntomas más notables de la crisis ecológica que ahora se le llama “calentamiento global” es el resultado del efecto acumulativo de más de 200 años de una civilización industrial que no escatima en la emisión de sustancias toxicas y de manera insensible no le importa como esto daña al orden natural ya que sus fines principales son la producción desmedida de mercancías y la búsqueda de ganancias. Los gases de efecto invernadero se han venido acumulando en el globo terráqueo desde la llamada revolución industrial pero las mayores concentraciones han ocurrido en el contexto de la globalización neoliberal. El calentamiento global junto con otras formas relativas de "cambio climático" como "el niño", son manifiestos en fenómenos como la reducción de las masas glaciales que podrían eventualmente causar tsunamis en varias partes del mundo, y en las enormes inundaciones a través del planeta que están causando un resto de muertes y destrucción agrícola. La lista de calamidades que han sido resultado de una combinación de factores históricosociales y "naturales" es enorme desde inundaciones catastróficas en Pakistán, derrumbes urbanos en Rio de Janeiro y el Cuzco, desastres mineros en Chile, derretimiento de cerros nevados junto con sequia de ríos y lagos en Bolivia y Perú, y terremotos en Haití, hasta huracanes gigantescos en las Antillas y Nueva Orleans. En fin, la civilización capitalista occidental está destruyendo el planeta y hay un consenso global creciente de que hay que tomar medidas radicales al respecto como claramente lo demostraron las cumbres en Copenhaguen y Cochabamba. Aquí es importante subrayar el liderato de Evo Morales en la cumbre de Copenhaguen y destacar que su rol en este contexto como primer Presidente Indígena de Bolivia revela el carácter protagónico de los movimientos indígenas en la conciencia ecológica que informa los nuevos paradigmas de emancipación. ${ }^{36}$

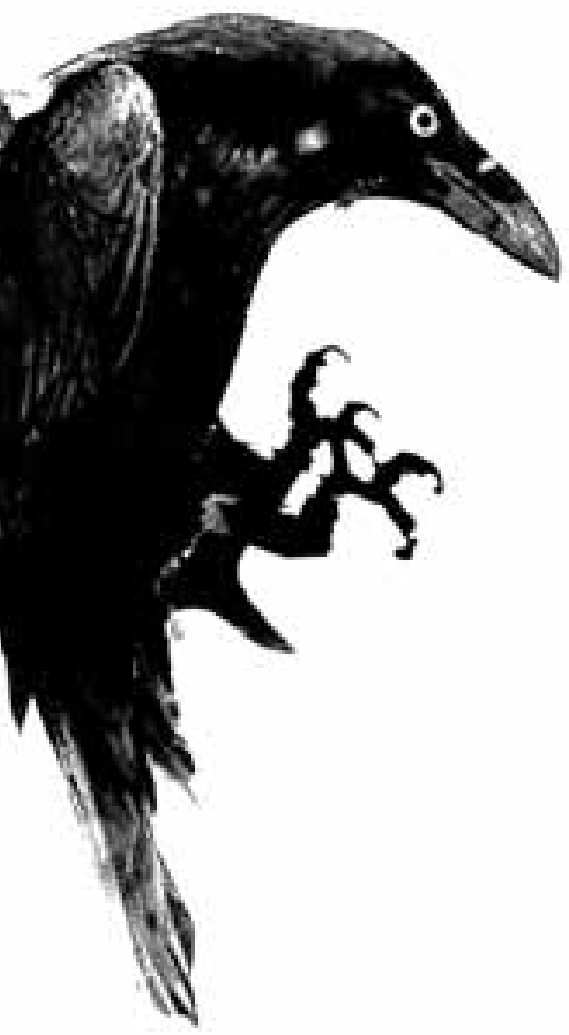

La crisis de acumulación también ha implicado un aumento significativo de las estrategias del capital transnacional para obtener mayores ganancias a través de la agroindustria y la minería, lo que ha implicado intentos de colonización de territorios relativamente fuera de su control tales como el Pacifico Colombiano y las tierras ancestrales de comunidades indígenas en la región Andina, para explotarlos con megaproyectos como el establecimiento de plantaciones de palma africana y la extracción de oro. Estas iniciativas, promovidas por estados como el de Colombia y Perú, son desafiadas por movimientos sociales de Afrodescendientes, Indígenas, y Campesinos que se oponen a la colonización de sus territorios ancestrales por el capital transnacional a la vez que afirman su identidad étnico-racial y promueven una política ecológica que promueve formas de economía en armonía con el ambiente y en base a modos comunitarios de autogobierno. Esta conciencia ecológica es un componente clave en las nuevas culturas políticas de los movimientos antisistémicos en la época presente, una suerte de "nuevo sentido común contrahegemónico" como le llama de Sousa Santos. ${ }^{37}$ 
La cuestión ecológica se refiere directamente a la crisis alimentaria provocada por una conjunción de la nueva "revolución verde" con el grave desequilibrio ambiental y la hiperinflación del capital financiero. En otras palabras, la mecanización de la producción agrícola, la agroindustria a gran escala, y el modelo extractivista y exportador, junto con las políticas neoliberales de libre mercado a favor de las corporaciones transnacionales del agrocomercio, han tenido como consecuencia el empobrecimiento, desplazamiento y destierro de las masas campesinas del mundo y la desnacionalización de la producción agrícola, lo que se agrava con la financiarización de la economía y con los desastres ecológicos. Esta dinámica apunta hacia la profundización del hambre, la desnutrición, y la alimentación tóxica debido a la proliferación de semillas transgénicas y la agricultura química promovidas por el gran capital agrícola sobre todo de los Estados Unidos. El año pasado, debido al aumento del precio de los alimentos, el número de hambrientos crónicos subió de 840 millones a 950 millones. Estudios de organismos de paz revelaron que con 24 mil millones dólares/año — apenas un 2,6\% del presupuesto militar total — se podría reducir a la mitad el hambre del mundo. Con 12 mil millones —un 1,3\% del referido presupuesto - se podría asegurar la salud reproductiva de todas las mujeres de la Tierra. Aquí es importante ver claramente la relación entre el gran capital agrícola (cuyo ejemplo más visible son la complicidad para monopolizar tanto producción como comercialización y finanzas por la agroindustria estadounidense, sobre todo por la Corporación Monsanto), con las políticas estatales de abrir mercados que promueven la inmiseración y expropiación de los campesinos y por ende desempleo y pobreza, la erosión de la tierra, y la producción de alimentos nocivos a la salud. Estas condiciones han servido de base para el crecimiento de los movimientos campesinos como vemos claramente en la coalición mundial Vía Campesina y en grandes organizaciones como el Movimiento de los Sin Tierra en Brasil que enuncian un nuevo discurso de poder campesino, soberanía alimentaria, y armonía ecológica que articula una nueva racionalidad no solo económica sino de vida colectiva para todo el planeta.

La crisis ecológica revela de la forma más nítida y profunda todas las contradicciones del patrón de poder en esta era. Como bien lo pinta Edgardo Lander, "este patrón está en guerra sistemática con la vida misma en todas sus expresiones- el agua, la pesca, la tierra, las semillas, los bosques, la biodiversidad genética- lo cual no es sostenible." ${ }^{38}$ A dicha situación responden y ofrecen alternativas una fuerte constelación de movimientos ecológicos pero los poderes estatales y del capital transnacional responden a las resistencias "con racismo y militarización" y con supuestas "soluciones tecnocráticas y de mercado". Por su parte, Elizabeth Peredo Beltrán, sintetiza claramente el significado fundamental de la cuestión ecológica en el contexto de la crisis actual cuando escribe:
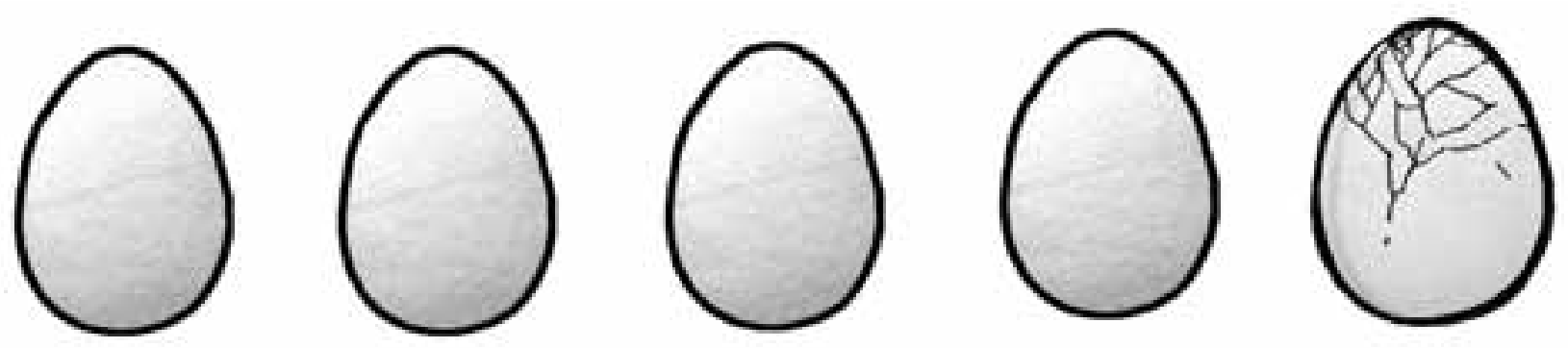
"Hablar de la crisis climática es hablar de la crisis del sistema capitalista o más bien de la crisis del mundo a raíz del sistema capitalista y del colonialismo que durante siglos explotaron sin límites los recursos naturales, las culturas de los pueblos, sus saberes y conocimientos y las fuerzas de trabajo de miles de millones de personas, de aquellas que sostienen con su esfuerzo y sus energías la vida de las sociedades del mundo. Así, el cambio climático que a estas alturas puede considerarse como uno de los mayores crímenes cometidos contra la humanidad y contra la Madre Tierra, es el síntoma más claro y paradigmático de una crisis civilizatoria que ha tocado límites." ${ }^{39}$ Tocando el mismo tambor, afirma el intelectual cubano Gilberto Valdés Gutiérrez, "La aspiración es por la justicia, la equidad, pero no desde el paradigma liberal-democrático, sino desde un verdadero y significativo transito civilizatoriocultural, de un nuevo modo de relacionamiento social y con la naturaleza.” ${ }^{\prime 0}$

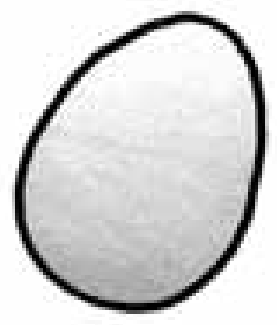

La severidad de la dimensión ecológica de la crisis de la civilización occidental capitalista ha colocado la política ecológica en el centro de los debates claves tanto ético-políticos como epistémicos. A propósito de la implicación de fondo de la crisis ecológica Lander argumenta que en este "nuevo momento histórico de crisis terminal del patrón de poder" hay "un nuevo sentido del tiempo" donde la velocidad de la crisis avanza rápidamente junto con peligros inminentes con posibilidad de daños irreparables, lo que crea urgencia y necesidad tanto de redefinir las categorías de análisis como de actuar con la mayor rapidez posible. Dicha condición apunta hacia una estrategia epistémica de "redefinir las categorías y el sentido común" como las nociones de "bienestar, riqueza, y progreso" correspondiente a una nueva "relación entre los seres Humanos y el resto de la vida". Redefinir las relaciones sociales entre los seres humanos, y de los humanos con otras formas de vida y con el resto del cosmos, de relaciones de apropiación, competencia y explotación, a relaciones de armonía, reciprocidad y complementariedad son algunas de las premisas principales de la política ecológica. Estos principios de política ecológica se oponen a la racionalidad occidental capitalista y suponen una crítica de sus categorías, valores, discursos, y practicas fundamentales como son las nociones occidentales de "progreso" y "desarrollo". ${ }^{41}$

Una de las características claves de los nuevos discursos críticos y de las alternativas de futuro que se construyen desde abajo es el cuestionamiento de los paradigmas occidentales de "progreso" y "desarrollo". Los imaginarios "pos-desarrollistas" que informan la nueva ecología política no es una creación de intelectuales radicales occidentales, es en gran medida producto de las racionalidades de vida que no han podido ser colonizadas por la civilización occidental capitalista como se expresa en la conciencia ecológica profunda de los movimientos Indígenas y en movimientos Afrodescendientes como el Proceso de Comunidades Negras en Colombia que abogan por una forma existencial que conjuga propiedad colectiva, derechos humanos múltiples, afirmación de identidad étnico-racial y cultural, autogobierno comunitario, y etno-desarrollo sustentable con armonía ambiental y social, en lucha contra los megaproyectos corporativos y políticas estatales de corte neoliberal. ${ }^{42}$ Dichas políticas ecológicas vernáculas se combinan con las versiones más críticas y radicales de la política verde occidental, como por ejemplo la propuesta de Elmar Alvater de un "socialismo solar" que contrasta con el contrasentido de un "socialismo 
petrolero" que alguna vez se ha escuchado en Venezuela. Aquí se revela uno de los pilares de la crisis ecológica que es la cuestión energética. Esto nos plantea una serie de preguntas: ¿Cómo remplazar las fuentes fósiles como forma principal de provisión de energía? ¿Qué implicaría todo esto para los nuevos patrones de acumulación de capital, modos de consumo, y maneras de definir necesidades y estilos de vida? ¿Cuáles son las implicaciones políticas mas generales de lo que hemos definido como critica de la economía política y nueva política ecológica?

\section{Crisis Política: Democracia Liberal \& Hegemonía Imperial}

La dimensión más estrictamente política la podemos definir como una doble crisis, por un lado la erosión definitiva de la democracia liberal representativa, y por otro lado pérdida de hegemonía imperial. ${ }^{43}$

Comenzamos con la crisis de la democracia liberal representativa que ha servido desde el siglo XVIII tanto de ideología hegemónica del estado moderno como de forma política paradigmática de los estados metropolitanos. A pesar de que en los discursos liberales se postula una ecuación entre capitalismo y democracia, el archivo histórico demuestra que el carácter despótico del poder burgués ha sido transformado en formas políticas democráticas a partir de las luchas históricas de 1@s subaltern@s en aras de recursos, representación, y reconocimiento. Desde las llamadas revoluciones burguesas a finales del siglo XVIII (la revolución Francesa y la guerra de independencia que constituyo los Estados Unidos), las formas democráticas de la modernidad han sido producto de luchas históricas, sin dejar de configurar regímenes de poder que subordinan sectores de la ciudadanía y sujetan poblaciones subalternizadas (otredades coloniales, étnico-raciales, sociales, sexuales y de género). Los sujetos que han sido excluidos y marginalizados de los beneficios de la ciudadanía moderna (derechos, participación, y pertenencia plena a una comunidad política) han luchado históricamente tanto por la extensión del sufragio ciudadano (mujeres, sujetos negativamente racializados, otredades sexuales), como por la proliferación de los derechos (civiles, políticos, sociales, culturales, sexuales) y por la democratización de la democracia (representativa, participativa, deliberativa) a escalas locales, nacionales, regionales, y globales.

Esta relación entre tendencias despóticas en el poder burgués (capitalista, racial, y patriarcal) y las luchas históricas de los sectores subalternos le ha dado un carácter contingente e inestable a la forma política paradigmática de los centros del poder occidental que es la democracia liberal representativa. Las coyunturas histórico-mundiales de crisis sistémicas y olas de movimientos antisistémicos se han caracterizado por un lado por el salto al relieve de los modos mas despóticos del poder burgués (como el racismo europeo de los 1930s junto con las dos grandes guerras de occidente en la misma época), y por otro lado por la emergencia de grandes movilizaciones, movimientos y revoluciones (como la revolución Mexicana, revolución Rusa y revolución China a principios del siglo XX, y los movimientos Pan-Africanistas y comunistas en los 1930s). 


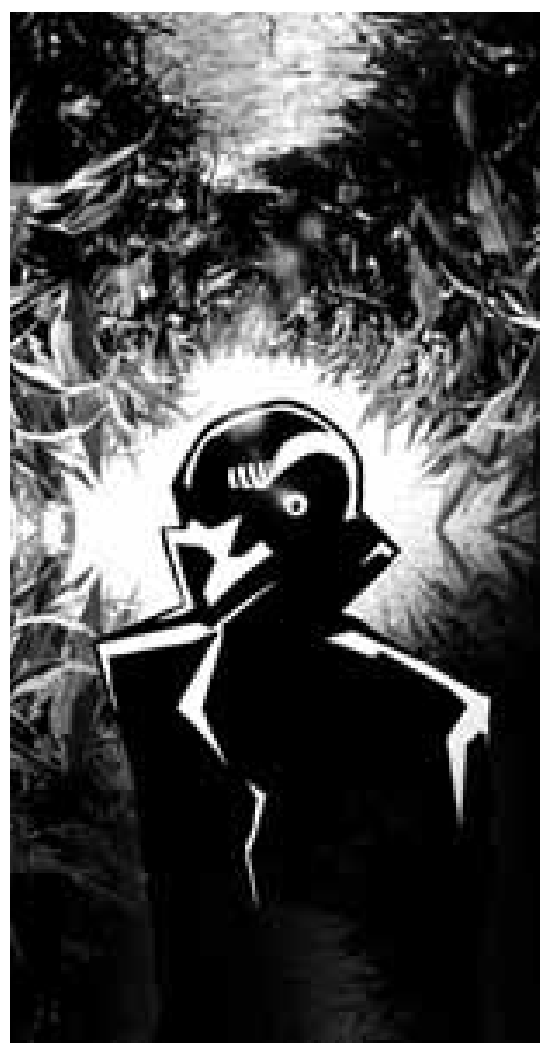

Desde la perspectiva de la colonialidad, la otra cara de la modernidad, los sujetos coloniales han protagonizado luchas histórico-mundiales por libertad, justicia, e igualdad en el ámbito de lo político, al menos desde la revolución haitiana (1791-1804) que fue la revolución social más profunda de la llamada "Era de las Revoluciones", la única que simultáneamente fue anti-colonial y anti-esclavista a la vez que afirmo la negritud como una identidad positiva y como premisa para la constitución del sujeto nacional. En el mundo colonial, donde diferentes olas de luchas por la descolonización transformaron en "neocolonial", "dependiente", o "periférico" a estos espacios en relación a los centros de poder occidental, ${ }^{44}$ la democracia liberal tiende a ser más débil y vulnerable a los vaivenes de los procesos de acumulación de capital y las luchas históricas.

Argumentamos que la crisis actual conlleva a una erosión definitiva de las formas democráticas de la modernidad capitalista tanto en los centros de poder occidental como en los espacios subordinados. Para este efecto convergen una serie de factores incluyendo: la centralización del poder político en el ejecutivo en detrimento de la representación y participación ciudadana en los escenarios nacionales, la formación de un bloque global imperial donde se toman decisiones claves para el mundo al margen del escrutinio de los ciudadanos, y la pérdida de capacidad y voluntad de los estados de servir como agentes efectivos en la redistribución de poder y riqueza.

Una de las características de la organización del poder político en la era de la globalización neoliberal es una combinación de mayor concentración del poder ejecutivo en detrimento de la participación ciudadana, junto un giro participativo hacia el gobierno local. Esto ha implicado una serie de paradojas en la organización política entre la cuales podemos destacar el entrejuego de mayor participación local con menor incidencia publica en los escenarios nacionales. Esta contradicción entre la socialización relativa del poder local y la centralización y privatización del la autoridad estatal se corresponde a la des-nacionalización del poder a través del establecimiento de estados neoliberales que tienen a servir de agentes globalizadores para las fracciones exportadoras y financieras de las burguesías criollas a la vez que responden y sirven a instituciones del capital global como corporaciones transnacionales y el Fondo Monetario Internacional. Una de las consecuencias de esta condición políticoeconómica es que los estados cada vez tienen menor voluntad y mayor dificultad en proveer bienes públicos como educación y salud, y de resolver problemas de desigualdad social como desempleo y hambre, situación que se agrava en las actuales condiciones de crisis. Este conjunto de factores también exacerba las tendencias autoritarias en los estados modernos que crecientemente pierden la capacidad y voluntad de garantizar derechos civiles y políticos. Este tipo de fenómeno es conceptualizado por Boaventura de Sousa Santos en términos de la relación entre varias vertientes del "fascismo social" con las formas neoliberales de la democracia política. ${ }^{45}$ 


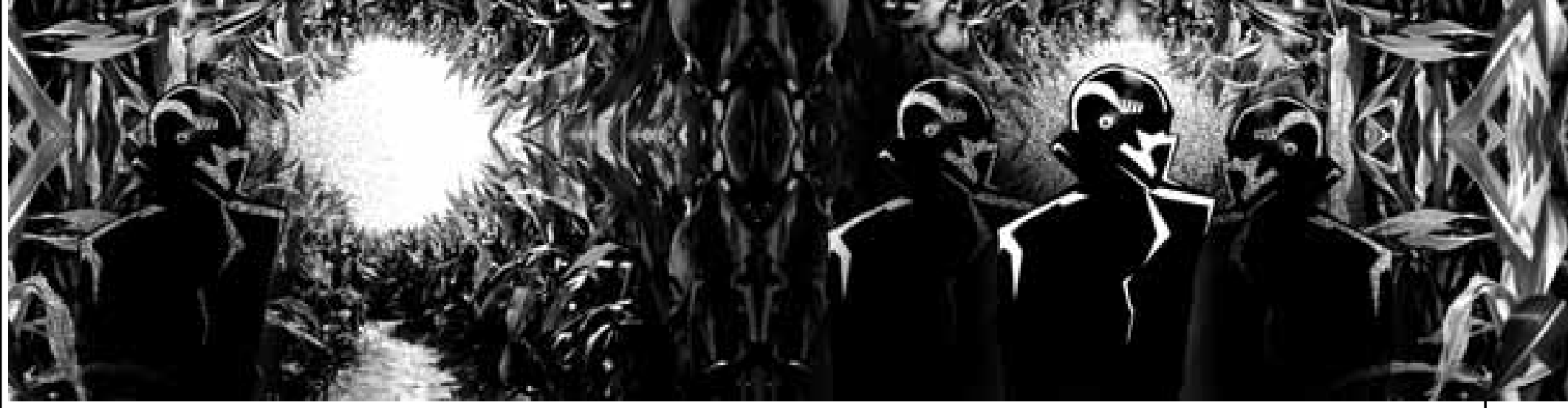

\section{Crisis de Hegemonía del Poder Imperial}

Si analizamos lo político desde sus aspectos formales e institucionales podemos distinguir cuatro escalas: local-regional, nacional, regional-supranacional y global. A escala mundial, la crisis se caracteriza por carencia de hegemonía combinada con perdida creciente de la soberanía relativa de los estados-nación sobre todo en la periferia. La ola de movimientos antisistémicos de los 1960s-70s marco el principio del final de la hegemonía yanqui en el sistema-mundo moderno/colonial capitalista. Dicha crisis de hegemonía es a la vez causa y efecto de la crisis de la economía mundial y el estado moderno. Aquí se conjuga la erosión de la democracia liberal representativa con la perdida de hegemonía global del estado imperial. En esta sección analizaremos dos aspectos de la crisis del poder imperial, el cual desglosaremos en sus dimensiones políticas y económicas.

Desde el ángulo económico la perdida de hegemonía estadounidense se perfila desde finales de los 1960s cuando comienza el déficit fiscal ligado a la guerra de Viet-Nam y en los inicios de los 1970s con la caída del dólar y el desmoronamiento del orden financiero creado en 1945 en Bretton Woods en conjunto con el ascenso de Japón y Alemania como competidores serios en el escenario económico mundial. La emergencia de la Unión Europea como entidad política y económica con su propia moneda en competencia favorable en relación al dólar junto al surgimiento del Este de Asia como la región con mayores tasas de crecimiento en los 1980s, dio inicio a procesos de regionalización que contrarrestaron la hegemonía económica norteamericana. La profundización de la crisis global del capitalismo neoliberal que estalla con la crisis financiera del 2008 consolida las tendencias a la regionalización de mercados regionales como MERCOSUR y viabiliza proyectos anti-imperialistas alternativos como el ALBA y su Banco del Sur. En palabras del economista peruano Oscar Ugarteche, "La crisis estadounidense, iniciada en 2007 y que se transformó en crisis global en 2008, está jugando un papel en la dinámica de la integración en América Latina. En las últimas dos décadas el comercio intrarregional ha crecido más que el extra regional y hay en marcha dentro del MERCOSUR y entre el MERCOSUR y la Comunidad Andina de Naciones (CAN) un impulso de integración económico real que se ha visto afectado por esta crisis." ${ }^{48}$ A la vez, la Unión Europea impulsa la organización de un Fondo Monetario Europeo como respuesta tanto a la crisis financiera global generada desde los Estados Unidos como a la insistencia de ese país de continuar sus políticas de no regulación del gran capital financiero. 
La pérdida de poder económico se conjuga con la primacía de militarización y guerra en lo que se ha denominado como el nuevo imperialismo estadounidense. ${ }^{49}$ Como decía sarcásticamente Arrighi, "Estados Unidos, mientras derroca regímenes delincuentes, primero en Afganistán y ahora en Iraq, es el país más endeudado del mundo (lo que le conduce a una) dominación sin hege-money." ${ }^{\prime 0}$ Es decir, la estrategia bi-partidista de jugar la carta militar para ganar otro "Siglo Americano", se ha convertido en una táctica de "dominación sin hegemonía” a la vez que ha exacerbado la crisis económica del país-imperio. Como demuestran Stiglitz y Bilmes en su libro The Three Trillion DollarWar, la guerra de Iraq solo ha beneficiado a las corporaciones punta del complejo militar-industrial, mientras la guerra ha sido financiada a costa del endeudamiento crónico de los EEUU, la carencia de recursos dedicados a la inversión productiva junto a la inflación del capital financiero, y la falta de provisión de bienes públicos. Así, la ofensiva guerrerista imperial articula las dimensiones económicas y políticas de la crisis de hegemonía.

El militarismo imperial estadounidense manifiesta una voluntad inútil de recobrar una hegemonía perdida para siempre, lo que le envuelve en una dinámica de guerra perpetua y violencias entretejidas que expresan una vertiente constante en el patrón de poder moderno/colonial a través de su larga duración..$^{51}$ Las tecnologías de terror imperial estadounidense que se han ensayado y elaborado a través de la historia de América Latina y el Caribe, como la contrainsurgencia, las múltiples violencias clandestinas, y la tortura, se han desarrollado en el llamado "medio oriente" donde ahora se ejecuta una especie de "presente colonial" especialmente en Afganistán, Iraq, y Palestina. ${ }^{52}$ Sin embargo, la ofensiva guerrerista no ha producido las victorias militares esperadas, a la vez que ha aportado al deterioro creciente del liderato político-diplomático de los Estados Unidos en la comunidad internacional y a su crisis económica, es decir a su pérdida de hegemonía.

Muchas personas a través del planeta invirtieron esperanzas en que la elección de Barrack Obama, el primer presidente negro, un intelectual del derecho constitucional que triunfo con una retorica de cambio, podría transformar de alguna manera el rol de los Estados Unidos en el mundo. Preguntarse por qué el presidente Obama terminó continuando la política anti-democrática de encarcelamiento sin juicio en Guantánamo y el Acta Patriótica, ahondando la guerra en Afganistán, escalando la presencia militar en América Latina, continuando con el Director del Pentágono de George W. Bush, esgrimiendo los discursos y políticas de la "guerra contra el terror”, y nombrando varios de los arquitectos del régimen de especulación financiera que desemboco en la crisis de 2008 revela más de la naturaleza del poder imperial y de la crisis actual del patrón de poder que del carácter político de Obama. Los economistas renacidos de ser neoliberales a devenir neokeynesianos como Paul Krugman y Joseph Stiglitz critican el programa de "estimulo económico" de Obama por no proveer suficiente fondos para la recuperación, pero como hemos argumentado a través de este escrito, el problema es mucho más de fondo. Las políticas de Obama son sintomáticas de como la combinación de la crisis económica con la erosión de la democracia liberal representativa y la pérdida de hegemonía apuntan hacia las formas más autoritarias del poder imperial. La política imperial de mano dura es indicadora de la perdida de hegemonía como se demostró con la

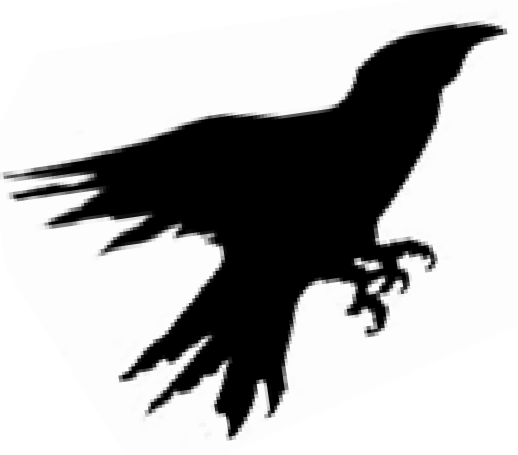




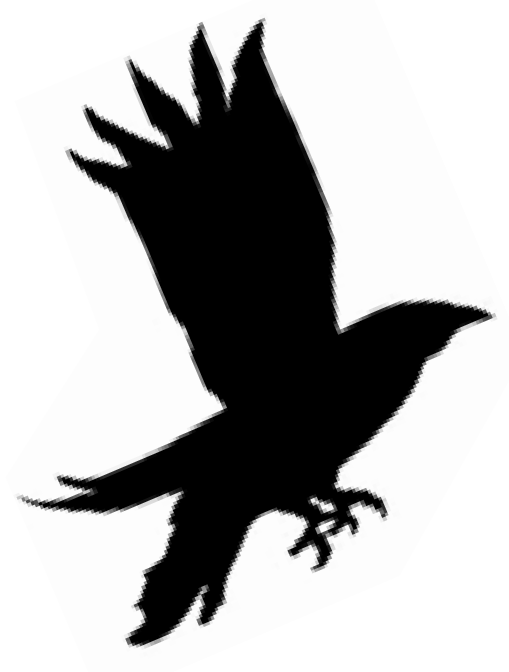

bienvenida a Cuba en la última conferencia de la Organización de Estados Americanos y el fuerte rechazo a las bases militares yanquis en Colombia en la última cumbre de UNASUR. Los intentos fallidos de renovación de la hegemonía norteamericana llevan a una política maquiavélica de imposiciones diplomáticas y militarismo que sostienen una dinámica de desarticulación del orden político internacional a la vez que una erosión de la democracia liberal en el campo político estadounidense.

Más allá de la perdida de la hegemonía estadounidense, la crisis actual representa una crisis de la hegemonía occidental y de las culturas capitalistas. En este sentido, la era presente se podría caracterizar con el concepto gramcsiano de interregno como un periodo transicional donde no hay un hegemón, existe un caos en el sistemamundo, y más aun cuando hay una crisis raigal en el patrón de poder moderno/ colonial. Ahora nos detendremos brevemente primero en las dimensiones éticas y subjetivas de la crisis, para luego discutir rápidamente sus aspectos epistémicos.

\section{Dimensiones Culturales, Éticas, Epistémicas, y Subjetivas de la Crisis Actual}

Las dimensiones políticas de la crisis civilizatoria se corresponden a el deslinde de dos tipos de crisis que plantea el intelectual boliviano Luis Tapia, por un lado el malestar en la estabilidad de las instituciones del poder dominante como el estado y la economía; y por otro lado en su desafío y cuestionamiento a partir de las practicas emancipatorias de muchos movimientos sociales y espacios subalternos contra las formas patriarcales, de alimentación, de explotación, organización política, ecología, y de producción de conocimientos que dominan la vida social de nuestra región y el mundo. ${ }^{53}$

Lo político se corresponde a las dimensiones culturales, epistémicas, éticas y subjetivas de la crisis del la civilización occidental capitalista. En este registro se integran la crisis de valores, de proyectos de vida, de modos de producción y comunicación de conocimientos, y de formas de identidad y subjetividad imperantes en la civilización occidental capitalista. Esto es en parte resultado del fracaso de los modelos de desarrollo socio-económico, ecología, y organización política de la modernidad capitalista como también de sus lógicas culturales hegemónicas con sus elementos éticos, estéticos, cognoscitivos, e identitarios. En este sentido planteamos que la liberación de historias, memorias, conocimientos, y modos de vida no-occidentales es un síntoma positivo de esta crisis.

Una de las peculiaridades y novedades de la crisis actual es su severidad en tanto crisis de las estructuras de conocimiento de carácter eurocéntrico-occidentalista, en las formas hegemónicas que también conceptualizamos como "colonialidad del saber" ${ }^{54}$ Su contraparte en la búsqueda de justicia epistémica se ha convertido en uno de las características y reclamos principales de una nueva ola de movimientos antisistémicos que surgen como actores protagónicos en los procesos crecientes de des/colonialidad del poder y el saber produciendo un nuevo episteme y racionalidad de vida. Cada vez más las comunidades subalternas, los espacios de movimiento 
social, y los escenarios de nueva izquierda se afirman como "insurgencias político epistémicas" que politizan la cuestión del conocimiento como uno de los campos de lucha principales y por ende uno de los flancos más débiles de la civilización occidental capitalista. La "insurrección de los saberes subyugados" toma diferentes formas desde la reivindicación de "pensamiento propio” Afrodescendiente e Indígena, hasta reclamos de reconocimiento de los movimientos sociales como productores de teoría y saber sistemático y la reivindicación de la "investigación activista" y la "investigación acción colaborativa" a través de diálogos y "ecologías de saberes". ${ }^{55}$ Todo esto implica tanto "cambiar la geografía de la razón” (como reza el lema de la Asociación de Filosofía del Caribe) como redefinir los referentes del conocimiento critico más allá del pensamiento occidental. En fin, la des/colonialidad del saber se ha convertido en objetivo político y práctica principal de una nueva constelación de movimientos antisistémicos que construye cotidianamente nuevos modos de producción y comunicación de conocimientos.

En la misma vena fluyen las dimensiones culturales de la crisis. Una de las características de la coyuntura actual es la proliferación de "guerras culturales" que desafían y proponen alternativas a la llamada "alta cultura" y a la cultura corporativa mass-mediática occidental en todos los ámbitos de la vida social desde lo estético y los saberes hasta la sexualidad y las culturas políticas. Esto implica una suerte combinada de culturas emergentes desde industrias culturales vernáculas politizadas (como la Champeta en Colombia, el Afro-Funk en Brasil, y el Hip-Hop Cubano), hasta diversos movimientos culturales, que juntas conforman tanto la afirmación del valor de culturas ancestrales y culturas populares como la insurgencia de culturas de des/colonialidad y liberación. Estas corrientes culturales van componiendo políticas culturales y culturas políticas que van dando forma a lo que de Santos denomina como un "nuevo sentido común". ${ }^{56}$

El surgimiento de nuevos lenguajes, géneros culturales y discursos críticos, está asociado a la afirmación de valores y modos de subjetividad que desafían lo ética capitalista y los estilos de vida promovidos por la civilización occidental. La emergencia de valores pos-capitalistas y de imaginarios políticos pos-liberales van vinculados al surgimiento de lugares de vida alternos y alternativos a las culturas y modos de vida dominantes. Estos espacios vitales van nutriendo tanto de comunidades subalternas (Afrodescendientes, Indígenas, campesinas, márgenes urbanos) como de espacios de movimiento social (étnico-racial, social, feminista, juvenil, etc.) que en conjunto van constituyendo "contra-públicos subalternos". ${ }^{57}$

La crisis ética de la civilización occidental capitalista no es solo de valores sino más aun de convivencia, modos de vida, e intimidad, en fin de inter-subjetividad. La crisis existencial de sentidos y horizontes de vida se expresa en los altos índices de suicidio, drogadicción, violencia domestica, y declaraciones de aburrimiento y falta de esperanza en muchos jóvenes sobre todo en los centros occidentales. Santiago Alba Rico en su artículo Crisis capitalista: la racionalidad del abismo señala "entre los años 1997 y 2005, más de 150.000 campesinos se han suicidado en la India, despojados de sus tierras o arruinados por las grandes multinacionales de la alimentación, con Monsanto a la cabeza” y añade que "en los últimos seis meses, se han suicidado 9 
millonarios en todo el mundo; es decir, una media de 1 millonario cada 20 días" mientras que "desde el año 1997, sólo en la India se ha suicidado un campesino cada 32 minutos" concluyendo que si "Los ricos se suicidan: es que hay una crisis del capitalismo. Los pobres se suicidan: es que hay sencillamente capitalismo." ${ }^{58}$ En suma, la crisis exacerba las patologías de la vida cotidiana en la modernidad capitalista.

En el terreno de la subjetividad la crisis actual se manifiesta como desafío de fondo a las definiciones y formas occidentales de la identidad, el yo, y el ser. ${ }^{59}$ Las categorías moderno/coloniales de identidades étnico-raciales subalternizadas tales como "indio" y "negro", también sirven de base para la re-afirmación positiva de subjetividades politizadas capaces de promover tipos de comunidad y modos de vida a contrapunto de las formas dominantes en la civilización occidental capitalista. La hegemonía ético-política, epistémica, y estética del yo occidental, definido como hombre blanco, heterosexual, propietario, y letrado en la tradición europea; se corresponde a la emergencia de movimientos (ecológicos, étnicoraciales, feministas, culturales, intelectuales) que desafían todas las aristas del patrón de poder moderno/colonial que produce este sujeto como paradigmático. En este sentido, en el corazón de la nueva ola de movimientos antisistémicos hay una nueva cultura política que busca no solo transformar las estructuras de sentimiento, saber, y poder, sino más aun la des/colonialidad del sujeto y la re-invención de las subjetividades. En este contexto, las luchas por la producción, definición y ejercicio de la subjetividad se tornan claves. Como afirma Quijano, "nunca como hoy para los que controlan este patrón de poder fue tan absolutamente necesario el tener el control de la producción de subjetividad, memoria, identidad, y conocimiento", a lo que suma que esto implica "des/colonializar la subjetividad" y "descapitalizar nuestras mentes y sentimientos". ${ }^{60}$

La des/colonialidad de la subjetividad en sus múltiples dimensiones (existenciales, afectivas, cognoscitivas) tiene variedad de avatares desde luchas por defender territorios y racionalidades de vida ancestrales como afirman muchas comunidades Afrodescendientes e Indígenas, hasta la construcción de nuevas identidades y subjetividades, tipos de comunidad, y modos de vida en armonía social y ambiental, como lo expresa claramente el concepto de permacultura.

En resumen, todo lo argumentado demuestra el fracaso de los modelos de desarrollo socio-económico, ecología, y organización política de la modernidad capitalista, como también de sus lógicas culturales hegemónicas con sus elementos éticos, estéticos, cognoscitivos, e identitarios. En realidad, vivimos la mayor y más profunda crisis de la civilización occidental capitalista, que bien podría ser su crisis terminal y definitiva ya que se cuestionan sus fundamentos mismos al implosionar sus tendencias más perversas y por la insurgencia de alternativas civilizatorias. 


\section{Crisis Societal y Nueva Ola de Movimiento Antisitémicos}

Es imperativo entender las crisis en relación a las luchas y acciones colectivas que denominamos movimientos antisistémicos para significar olas de luchas con vocación y/o efectos de desafiar y transformar el patrón de poder. La crisis sirve de marco y contexto para la emergencia de nuevos focos de resistencia, subjetividades políticas, trincheras de lucha, proyectos y horizontes de futuro los que el Sub-Marcos denomina como la "La Cuarta Guerra Mundial" cuyas primeras expresiones se pueden trazar de forma diversa, al Caracazo de 1989 en Venezuela, al levantamiento Zapatista de enero de 1994 en el sur de México, o a las protestas contra la reunión de la Organización Mundial de Comercio en Diciembre de 1999, en Seattle, Washington en los Estados Unidos, hasta los procesos de Foro Social y cumbres de pueblos y movimientos de carácter diverso. Es decir, la crisis del patrón de poder también ha implicado la emergencia de nuevos sujetos sociales de transformación histórica que a partir de una pluralidad de identidades políticas y culturales han presidido una diversidad de luchas que confrontan y desafían la modernidad/colonialidad en sus múltiples dimensiones. Dichos sujetos se articulan y expresan en una constelación de movilizaciones, luchas campanas, movimientos, espacios y organizaciones que conceptualizamos como movimientos societales con efectos des/coloniales, o movimientos antisistémicos.

La crisis civilizatoria se caracteriza por desafíos variados desde una pluralidad de lugares y perspectivas al patrón de poder a partir de las practicas emancipatorias de una amplia gama de movimientos sociales y espacios subalternos contra las formas patriarcales, de alimentación y consumo, de explotación, organización política, ecología, y de producción de conocimientos que dominan la vida social desde escala locales y regionales hasta el nivel global. En esta coyuntura de crisis y transformación no es suficiente hablar de movimientos sociales sino más aun de movimientos societales, acciones colectivas que tengan la capacidad de provocar cambios a nivel de la sociedad en su conjunto con vocación y/o potencial de llegar a ser de carácter antisistémico no solo en su intencionalidad sino por sus efectos. Los movimientos sociales en tanto acciones colectivas y campos de acción y comunicación con vocación y capacidad de alterar el status quo pueden ser de intencionalidad, alcance, y efectos pro-sistémicos o antisistémicos. La crisis también tiende a promover movimientos de derecha con sus culturas de "populismo autoritario" como el que se expresa en el Tea Party en los Estados Unidos y las acciones colectivas anti-inmigrantes en Europa. ${ }^{61}$ En contraste, usamos la noción de movimientos societales tanto para distinguir movimientos indígenas que representan otras formas de sociedad y racionalidades de vida (ecológicas, económicas, autogobierno) ${ }^{62}$, como la capacidad conjunta de los movimientos sociales de producir transformaciones significativas en el orden social y por ende de poner en jaque el patrón de poder moderno/ colonial. ${ }^{63}$ Este efecto de des/colonialidad de la nueva ola de movimientos sociales profundiza el sentido de lo antisistémico en la medida que desafían y subvierten todos los modos y mediaciones del poder moderno/ colonial desde sus espacios subjetivos hasta sus estructuras globales. A propósito del carácter cambiante del significado de los movimientos antisistémicos, escribe Gilberto Valdés Gutiérrez, "lo antisistémico actúa como horizonte de sentido de las resistencias y luchas del presente... un desafío integral a las formas de dominación múltiple del capital y a la civilización que ese engendro a nivel planetario. Se trata de un potente esfuerzo de ruptura radical con la lógica de dominación y sujeción del capital en todas sus modalidades, desde lo económico-productivo hasta lo simbólico-cultural." ${ }^{{ }^{4}}$ 
A contracorriente de la tendencia a abandonar la idea de revolución como vestigio antiguo, proponemos redefinirla como des/colonialidad en todos los ámbitos y a todo nivel y en tanto proyecto de liberación profunda. Como argumenta Mary Louise Pratt, uno de los móviles iniciales del concepto de movimiento social fue el de remplazar el de revolución. ${ }^{65}$ Proponemos rescatar revolución como categoría ético-política despojándola de su connotación leninista como "guerra de maniobra" para tomar el palacio de poder, de manera más afín a la noción gramsciana de "guerra de posiciones" que guía la idea de "bolsillos de resistencia" como las trincheras inmediatas de las luchas contra el capitalismo neoliberal y el nuevo imperialismo que postula el Sub-Comandante Marcos.

En esta perspectiva revolución denota transformación radical, un proceso de interrelación de múltiples cambios que ocurren simultáneamente donde ninguno prima necesariamente sobre el otro. Para un cambio tener carácter revolucionario ha de tener efectos críticos de carácter antisistémico, es decir, ha de subvertir e impactar la transformación del patrón de poder a varios niveles a la vez que ha de apuntar hacia nuevas formas de poder sin dominación. Además, el concepto occidental de revolución ha sido cuestionado y en parte remplazado por categorías no-occidentales como Pachakutik que implican transformaciones más profundas y fundamentales en el orden cósmico y por ende en todos los ámbitos de la vida planetaria. En este sentido revolución significa un proceso sostenido y profundo de forjar des/colonialidad, una mutación constante y creciente en áreas fundamentales tales como el trabajo, el sexo, la autoridad, y los imaginarios, todo lo cual supone tanto develar y revelar como transgredir y reemplazar el patrón de poder imperante. En este sentido la des/colonialidad necesariamente implica un proceso de democratización de todas las esferas de lo social desde el ensamblaje institucional (las fábricas, las universidades, las familias), hasta los modos de producción y comunicación de conocimiento, organización de la autoridad (estado, comunidad política), y producción de subjetividades.

Aquí analizamos la des/colonialidad como un proceso a largo plazo que va a la par con la colonialidad del poder. En este registro la des/colonialidad es un proceso, una tendencia clave en el sistema-mundo moderno/colonial capitalista que resulta del efecto combinado de las luchas cotidianas, las múltiples resistencias, y las diversas formas de organización que componen los movimientos antisistémicos. En dicha acepción la des/colonialidad no es simplemente un evento de tomar y reemplazar el estado colonial por un estado nacional, pero un proceso complejo y desigual con el fin y efecto de desmantelar las diversas formas de dominación y explotación del patrón de poder moderno/colonial. En este sentido hablamos de la des/colonialidad del poder, lo cual significa la creación de nuevas formas de poder donde no prime ni la dominación ni la explotación. Dicho objetivo de poder sin dominación supone el desmantelamiento de todas las formas de la colonialidad del poder desde las estructuras globales de distribución de riqueza y la geo-política imperialista, hasta la estructura eurocéntrica y occidentalista de autoridad del conocimiento y las jerarquías étnico-raciales y patriarcales en todas sus expresiones y a todo nivel. Es por eso que invocamos la des/colonialidad en una pluralidad de campos tales como la economía política, el saber, la cultura, y la subjetividad. En este sentido la des/colonialidad se convierte en significante principal del entramado de 
luchas que se entremezclan de forma compleja y muchas veces contradictoria en contra de los modos diversos de dominación y explotación, y a favor de formas más plenamente democráticas y socializadas del poder social. La des/colonialidad es tanto un proceso de lucha continua contra la colonialidad del poder en todas sus expresiones, como una articulación practica de formas de poder alternos y alternativos, y en este sentido se perfila como una política de liberación. Los gestores y actores principales de la des/colonialidad en tanto proceso son las organizaciones democráticas y los movimientos sociales que luchan por vías diversas a favor de la justicia social en su diversidad de definiciones y combinaciones, y por la libertad en el sentido concreto y profundo del concepto. En principio los agentes inmediatos de las luchas diarias por la des/colonialidad son sujetos de carne y hueso que luchan en contra de los diversos modos de dominación y a favor de alternativas democráticas en diversas trincheras de vida, que se pueden identificar desde los centros de trabajo y los espacios institucionales del poder, hasta los espacios más íntimos de la cotidianidad y la subjetividad.

Algunos movimientos como los Zapatistas en México, y el Movimiento de los Campesinos sin Tierra en Brasil han logrado integrar en su seno una pluralidad de luchas por la des/colonialidad, por la socialización y democratización del poder. Dichos movimientos les llamamos antisistémicos ya sea por su intencionalidad o por sus efectos de subvertir y de alguna manera también transformar el patrón de poder imperante. De esta manera podemos hablar del longue duree (o la larga duración) de las luchas por la des/colonialidad a la vez que subrayamos sus momentos cumbres, como los ejemplos de las revuelta Amerindias de Tupac Amaru y Tupac Khatari (un intento a gran escala de revolución indígena) y la revolución Haitiana (lidiada por esclavizados negros y que fue la revolución social más profunda de su época), el abolicionismo que fue el primer movimiento social global, la revolución soviética junto con la revolución mexicana a principios del siglo XX, los movimientos des/coloniales en África, Asia y el mundo Árabe hacia mediados del siglo XX, la emergencia de nuevos movimientos sociales en los 1960s, y finalmente la nueva ola de movimientos antisistémicos por justicia y paz hoy día que actúan y se articulan tanto a nivel global como local y que convergen en los Foros Sociales a nivel local, regional y mundial.

La des/colonialidad emancipatoria también la podemos entender como un proyecto, como un horizonte a seguir. En América Latina, esgrimiendo posturas antiimperialistas y en contra de la dependencia político-económica y la subordinación cultural hablábamos en los 1960s de una segunda independencia, hoy podemos platicar de una nueva y definitiva política des/colonial. En tanto proyecto la des/ colonialidad no es un mero ideal, pero si un horizonte de metas de justicia social y democracia radical que ha de estar enraizado en las luchas y aspiraciones del presente.

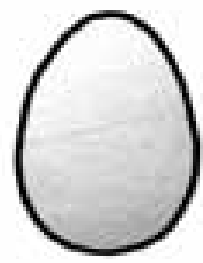




\section{Des/Colonialidad, Liberación \& Nuevas Racionalidades de Vida}

Algunos también caracterizarían la condición presente como una crisis de alternativas. ${ }^{66}$ Ahora se suele hablar del posneoliberalismo, pero con frecuencia sin una memoria histórica de fondo y sin un horizonte utópico alternativo. La nueva ola de movimientos antisistémicos, que en parte da continuidad a los movimientos de los 1960s-70s (ecológicos, feministas, diversidad sexual, étnico-raciales) a la vez profundiza los desafíos y prolifera los reclamos e identidades políticas; ya derroto, en praxis y teoría, las declaraciones triunfalistas que sentencian el "fin de la historia" a la vez que afirman que no hay alternativas al capitalismo, proclamadas por ideólogos del llamado "consenso de Washington" durante el clímax del paradigma neoliberal de globalización capitalista.

En esta región que desde finales del siglo XIX se le ha llamado Latinoamérica, que mas allá de nombrarla con Martí Nuestra América, ahora denominamos Nuestra Abiayala y Nuestra Afroamérica, se construyen alternativas diariamente desde los cambios en lo intimo y en las relaciones de género y sexualidad, las pequeñas trincheras de autogobierno comunitario y economía popular y solidaria, hasta los difíciles y contradictorios procesos de gobiernos de izquierda, que en su conjunto y a pesar de sus contradicciones van tejiendo redes des/coloniales que van construyendo futuros posibles. Lo que denominamos como una nueva política de des/colonialidad y liberación en América Latina, es un proceso complejo y desigual, lleno de obstáculos, contradicciones, y de cuestiones abiertas e inciertas. Esta es una temática vital en nuestro quehacer colectivo de construir conocimiento critico en el caminar de crear alternativas en el contexto de esta crisis de la civilización occidental capitalista, que debería ser motivo de otro artículo enfocado en sus tensiones y perspectivas centrales, pero para cerrar este escrito levantaremos alguna cuestiones claves. Primero voy a esbozar tres asuntos centrales para luego formular cinco preguntas claves.

Un primer tema fundamental es que hacer, en vista de la crisis de lo que llamábamos "socialismo actualmente existente", con la carencia de discursos unificadores de las luchas diversas a partir de proyectos comunes de emancipación. Entre las respuestas se encuentra el llamado "Socialismo del Siglo XXI" donde se realza tanto la cuestión de la "democratización de la democracia", como también la necesidad de transcender el obrerismo del socialismo de los siglos XIX y XX, integrando reivindicaciones étnicoraciales, sexuales, ecológica, y de género. A la misma vez, el socialismo del siglo XXI es en gran medida un discurso oficial de gobiernos que formulan y ejecutan, al menos parcialmente políticas neo-desarrollistas/pos-keynesianas incapaces de promover los cambios radicales de política ecológica, autogobierno comunitario, y desarrollo auto-sostenible, inspirados por racionalidades pos-capitalistas y pos-liberales, que son impulsados por los movimientos antisistémicos. En este registro, uno de los grandes dilemas es como crear e implementar estados real y efectivamente pluri-nacionales de corte inter-cultural y des/colonial en países como Bolivia y Ecuador. ${ }^{67}$ En Bolivia se van forjando, a pesar de serias dificultades y contradicciones, en gran medida a partir de racionalidades Indígenas de gobierno, economía, y cultura; una nueva constelación histórica que se denominado "socialismo comunitario". En esta vena, otro gran desafío es como construir socialmente y traducir institucionalmente la democracia 
sustantiva, es decir la creación de formas de ciudadanía y comunidad plenamente democráticas sustentadas por principios de igualdad sustantiva, reciprocidad, y deliberación colectiva, de una racionalidad política que envuelva una formación de poder sin dominación y una nueva hegemonía que conjugue en armonía el principio de la libertad individual con el principio de la autoridad localizado en la comunidad.

La ausencia de cualquier discurso maestro de emancipación junto con la proliferación de reivindicaciones y movimientos con sus respectivas subjetividades políticas, han orientado la formación de nuevas cultura políticas que tienden a respetar la pluralidad de diferencias, integrar el disenso como expresión democrática, y asumir el debate de diversidad de perspectivas y proyectos como parte integral de los procesos de transformación histórica. Todo esto implica tanto re-definiciones de los deslindes entre izquierdas, centros, y derechas, como también la emergencia de multiplicidad de políticas y proyectos de cambio radical. Un ejemplo significativo es el contraste entre las izquierda des/coloniales manifiestan en los movimientos Indígenas que traen categorías propias de sus prácticas comunitarias e imaginarios políticos (como "mandar obedeciendo") y de sus racionalidades de vida (como "buen vivir"), a contrapunto de las nuevas políticas radicales y expresiones del pensamiento crítico occidental como "la idea de comunismo" en Badiou y/o el proyecto de lo común en Hardt y Negri. ${ }^{68}$ Aquí cabe decir que las tradiciones de Pan-Africanismo Radical y Marxismo Negro han planteado políticas radicales y pensamiento crítico acentuando la centralidad del racismo y el colonialismo en la modernidad capitalista y sus alternativas desde principios del siglo XX. ${ }^{69}$ El negociar políticas radicales, pensamiento crítico y racionalidades de vida entre (pos) modernidad y des/colonialidad es uno de los grandes retos que tenemos hoy.

Un segundo tema central ligado al primero es como vislumbrar el horizonte de futuros posibles a la vez que lo vamos construyendo en el camino. En este registro, la des/colonialidad liberadora se puede ver como utopía en el sentido de Bloch y como utopística en el sentido de Wallerstein, es decir, como una estrella del norte que guie nuestras luchas presentes hacia claros objetivos de cambio radical, como un proyecto de liberación múltiple que a partir de las construcciones de futuro contenidas en nuestras prácticas nos conduce hacia la construcción de nuevas formaciones y relaciones de poder sin dominación ni explotación. Pero esta política de la esperanza y su horizonte de fututo ha de estar enraizado en las posibilidades y potencialidades del presente, lo que implica una doble tarea constante de análisis crítico y praxis transformadora. En esta época de crisis profunda y probablemente definitiva, el principio de la esperanza se torna más concreto e inmediato, se actualiza por medio de la mayor potenciación de la capacidad de los sujetos de accionar y desarrollar conciencia histórica. ${ }^{70}$

El tercer asunto que quiero levantar para concluir este articulo es el gran reto de cómo construir "unidad compleja" dado el carácter plural de las luchas presentes y por ende la gran diversidad de identidades y movimientos que las expresan y articulan. Hoy día las luchas son clara y explícitamente múltiples, a la vez que los actores de cambio y sus reclamos plurales, lo que hace más difícil el desafío de articular bloques contrahegemónicos que puedan construir y mantener espacios 
sociales fundados en principios de igualdad, reciprocidad, libertad, paz, y vida; en contraste a las lógicas de desigualdad, competencia, opresión, violencia, y muerte que imperan en la civilización occidental capitalista. Aquí el desafío es conjugar las cadenas de la colonialidad que corresponden a las distintas pero entrelazadas esferas de injusticia (social, étnico-racial, genero, sexualidad, ecología, etc.), hilando lazos de solidaridad para ir tejiendo luchas, identidades y movimientos en una suerte de "unidad compleja". ${ }^{71}$ Esta tarea de entretejer nudos de opresión con hilos de liberación es similar pero distinta a la propuesta de Laclau y Mouffe de articular una nueva hegemonía aumentando cadenas de equivalencia, porque no se trata de un significante flotante con referente vacio sino de un patrón de poder, una totalidad de carácter heterogéneo pero articulado. ${ }^{72}$ Tocando un tambor afín, Boaventura de Sousa Santos, ha propuesto y ensayado una metodología de "política de traducción" vinculada a una "ética de articulación” que busca construir coaliciones entre distintas luchas y movimientos para articular un "nuevo sentido común" para "reinventar la emancipación” y forjar bloques contrahegemónicos en aras de un proyecto político epistémico que llama "epistemologías del sur" y "cosmopolitismo subalterno". ${ }^{73}$ Este planteamiento es similar y traducible a nuestro argumento de conceptualizar las nuevas racionalidades de vida encarnadas en los movimientos antisistémicos de carácter anti-capitalistas y pos-liberales como una nueva política de des/colonialidad y liberación.

Concluimos haciendo cinco preguntas fundamentales del tipo que solemos debatir constantemente en espacios de construcción colectiva de conocimiento crítico y alternativas de vida, que varían desde asambleas comunales y caracolas zapatistas hasta conferencias universitarias. Estas preguntas y sus respuestas van conformando en el caminar una problemática común para reinventar la emancipación y crear colectivamente una nueva política de des/colonialidad y liberación.

1) ¿Qué significa y como construir formas justas, igualitarias, y plenamente democráticas del poder? Como conjugar el poder constituyente con la institucionalidad política, lo que Dussel representa como potentia y potestas usando el lenguaje de Spinoza. ¿Necesitamos refundar el estado y/o crear nuevas formas de institucionalidad y comunidad política? ; ¿qué significa y como se construye en términos concretos el "buen gobierno" y el "mandar obedeciendo"?

2) ¿Cómo traducir en proyectos de país/región/lugar y en políticas concretas la nueva racionalidad de economía, ecología, convivencia y gobierno connotadas por principios ético-políticos anti-capitalistas, no-occidentalistas, pos-liberales como Suma Kawsua (o "Buen Vivir” en Quechua) y Unbutu en lenguaje surafricano? , ¿cómo construir economías y ecologías de armonía entre todos los entes existentes a pesar de (y en relación con) los impulsos neo-desarrollistas y pos-keynesianos de los mismos gobiernos que declaran el socialismo del siglo XXI? , ¿cómo conjugar en práctica y teoría la política de lo posible con la utopía como horizonte de futuro?

3) ¿Qué estrategias de transformación radical se pueden perseguir a corto, mediano, y largo plazo, sin perder de vista las severas dificultades y contradicciones que implican los procesos de des/colonialidad del poder dentro de un sistemamundo moderno/colonial en condiciones de crisis raigal?

4) ¿Qué implicaciones tienen las transformaciones profundas que supone esta crisis raigal para los modos de producción, pedagogía, y comunicación de conocimiento crítico? ¿Cómo traducir los saberes e imaginarios anti-capitalistas y posliberales en nuevas racionalidades de vida y nuevas formas de poder sin dominación?

5) ¿Qué modos de supervivencia y espacios de convivencia son cerrados por el entrejuego de violencias que desatados por la crisis? A contrapunto, ¿qué nuevas formas de lucha resistencia y "re-existencia" se abren a partir de las estrategias de reinventar comunidad y vida que se abren a partir de las luchas, movimientos, y espacios alternos y alternativos que se van construyendo en el camino ? $^{74}$ 
En resumen, en su definición como momentos de malestar múltiple y profundo, las crisis son periodos de enormes sufrimientos, riesgos y dificultades, pero como épocas insostenibles que demandan cambios fundamentales también pueden ser eras de grandes transformaciones con el potencial de producir un contrato social más justo e igualitario, coyunturas donde podemos dar a luz futuros posibles, donde estamos más aptos para crear fuertes suertes de liberación. La crisis abre la posibilidad de potenciar plenamente nuestras capacidades como sujetos históricos. En este sentido la crisis representa un momento crítico de auto-creación de la sociedad y auto-afirmación de los sujetos con potencial de construir formas más justas e igualitarias de convivencia capaces de transformar radicalmente la condición humana. Nuestro gran reto es construir ese nuevo pacto social y modos de existencia colectiva e individual dándole contenido concreto y positivo al buen gobierno y buen vivir desde nuestras múltiples trincheras de lucha y dimensiones de vida. En este sentido, un modo de recrear el quehacer critico latinoamericano en el contexto del espectáculo de los bicentenarios, es el vislumbrar y reinventar América Latina como un proyecto de des/colonialidad del poder, desde cada sujeto, desde cada lucha y reivindicación, desde cada lugar, para así ir tejiendo futuros de liberación con autentica vocación de corazonar al mundo.

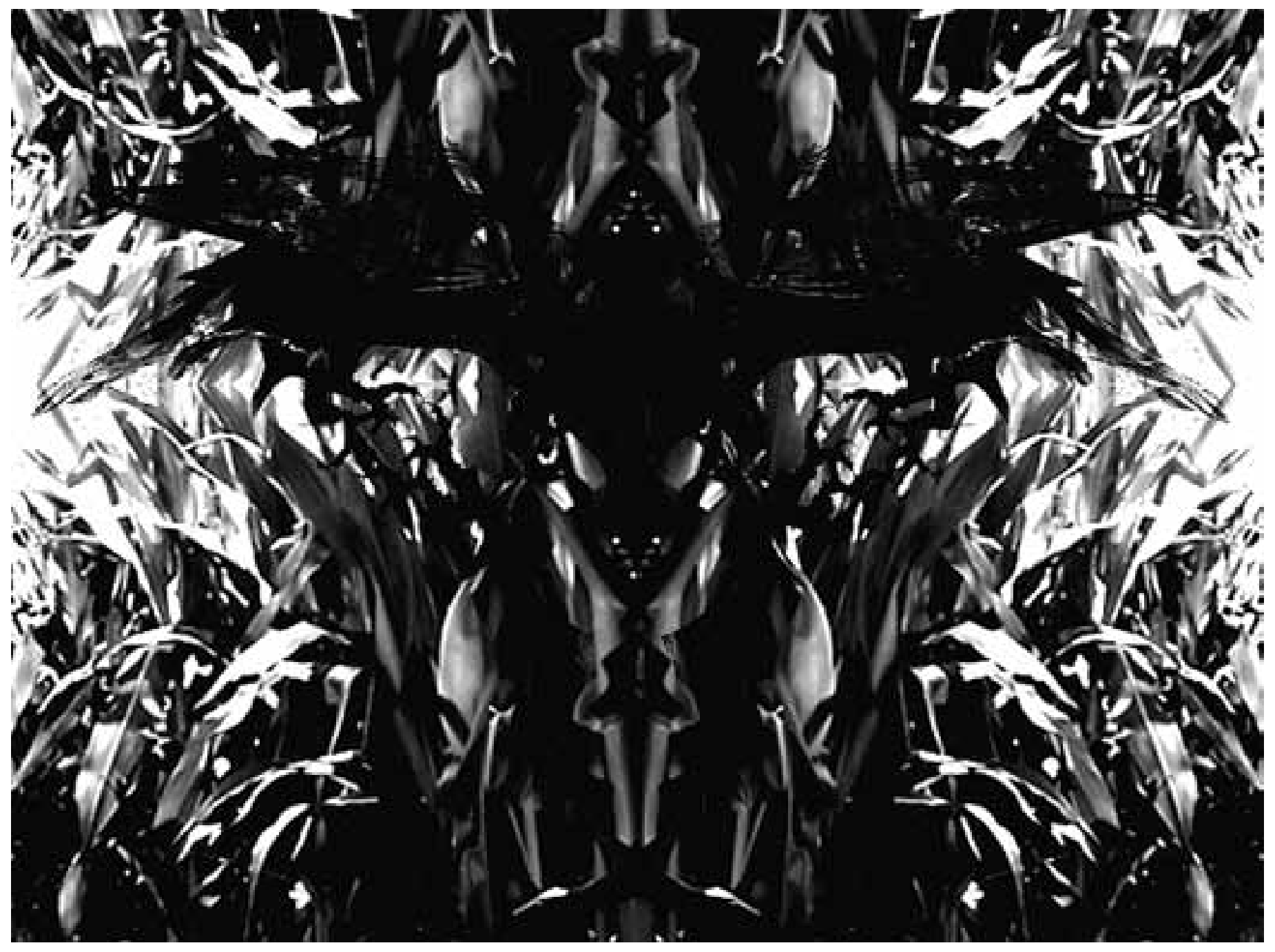


1 Ver Cesaire (1955). La traducción es mía.

2 Las citas proceden de Betto (2009)

3 Betto, ibid.

4 Ver Dussel (2007)

5 Ver Zemelman (2007)

6 Ver Huntington (1998). Para una critica clara y profunda ver Mamdani (2005).

7 Nuestro concepto de Civilización Occidental Capitalista es cercano a la manera en la cual Braudel (1992) y Wallerstein (1996) entienden el capitalismo como una economia-mundo que corresponde a una forma historica de civilización.

8 El concepto de capitalismo historico fue acunado por el sociologo estadounidense Immanuel Wallerstein (1996) para desarrollar un analisis mas historizado integrando elementos de las teorias del capitalismo sobre todo de Marx y Braudel.

9 Wallerstein $(1996,2010)$ ha utilizado los ciclos de Kondratieff para elaborar un analitica de las crisis en base a una logica macroeconomica mas compleja que se enmarca en un analisis de sistema-mundo que integra lo economico con lo cultural y lo politico.

10 Ver Aglietta (2001), Arrighi (1999), Gordon (1980), y Mandel (1972, 1978, 1995).

${ }^{11}$ Ver Arrighi, Hopkins, y Wallerstein (1999).

12 Estos fenómenos de carácter creciente y permanente los llamamos tendencias seculares para significar el carácter creciente de las crisis a medida que avanza la historia del capitalismo. Las crisis cíclicas que tienden a ocurrir periódicamente en contextos que combinan bajas significativas en las tasas de acumulación de capital con la emergencia de movimientos antisistémicos y alta concentración de guerras y violencia cada vez representan retos mayores y las condiciones de restructuracion son cada vez mas dificiles.

${ }^{13}$ El economista marxista pakistano Anwar Shaik ha sido uno de los defensores mas importantes de este argumento desde los $1970 \mathrm{~s}$. En relacion a la crisis actual Shaik argumenta que "Las causas son la baja productividad y competitividad estadounidense, y la baja participación de los asalariados en el Producto Bruto Interno.”Ver entrevista con Anwar Shaik http: / / criticadelae conomia.blogspot .com/2009/ 05/la-actual- crisis-es- la-primera- gran.html

${ }^{14}$ Este argumento del remplazo de capital productivo por capital financiero no se formula con certeza en Karl Marx sino en Fernand Braudel (1992), Giovanni Arrighi (1999), y Anibal Quijano.

${ }^{15}$ Este tipo de argumento se formula claramente en el análisis que hace Immanuel Wallerstein (2010) de la crisis reciente. En sus propias palabras, "El colapso económico en el cual estamos en medio de encontrarnos no es nada más que la expresión de los límites de la elasticidad de demanda."

${ }^{16}$ Este es el tipo de análisis realizado por Samir Amin (2009) y Andre Gunder Frank (1980), y tambien influye las interpretaciones de Arrighi (1999) y Harvey (2010).

17 Este tipo de análisis es principalmente argumentado por los economistas marxistas estadounidenses Rick Wolff y Stephen Resnick. Ver Wolff (2009).

${ }^{18}$ Uno de los expositores principales de este argumento hoy día es el geografo marxista David Harvey (2010).

${ }^{19}$ Segun Brenner (2009) "El principal origen de la crisis actual está en el declive del dinamismo de las economías avanzadas desde 1973 y, especialmente, desde 2000. El crecimiento económico en los EEUU, Europa occidental y Japón se ha deteriorado seriamente en cada ciclo en términos de indicadores macroeconómicos muy estándar: PIB, inversión, salarios reales, etc.”Tambien ver Callinicos (2010).

20 Ver Dumenil and Levy (2011).

21 Aquí observamos de nuevo que el análisis de Arrighi de las causas del descenso significativo de actividad del capital productivo se formula en términos de sobre-acumulación de capital.

22 Ver Arrighi (2007).

23 Samir Amin (2009) utitiliza un concepto similar que es el de "acumulacion por expropiacion". Tambien podemos ver ese tipo de analisis en varios de los teoricos de la dependencia incluyendo Andre Gunder Frank y Ruy Mauro Marini entre los cuales hay diferencias profundas, incluyendo. Para una critica del uso no suficientemente preciso y riguroso de este concepto en Harvey vease la tesis doctoral de Rajesh Bhattacharya (2010).

24 Esta cita se toma de la presentacion del concepto que hace Arrighi (2007).

25 Ver Harvey (2010). Todas las traducciones fueron hechas por mi.

26 Harvey, ibid.

27 Martinez Heredia citado en Valdes Gutierrez (2010) 
28 Para acortar la expresion del concepto de "patron de poder moderno/colonial", con frecuencia simplemente nos referimos al "patron de poder"

29 La critica de la economia politica es un concepto que Marx desarrola en El Capital para significar como las categorias de la economia politica como "mercancia" y "trabajo" encubren su caracter social en la vision superficial de su apariencia. Esta lectura del Marx maduro es continuada por Negri (1996). Para un analisis de la crisis desde esta perspectiva ver Meszaros (2010). La nocion de "capitalocentrismo" fue acunada por Gibson-Graham (2006). Planteando la critica desde una perspectiva de Estudios Culturales, Grossberg (2010) propone "rescatar la economia de los economistas".

30 Este tipo de analisis se lo hemos escuchado ha Quijano en varias conferencias incuyendo el encuentro internacional organizado por la Catedra America Latina y la Colonialidad del Poder de la Universidad Ricardo Palma en Lima, Agosto 3-5, 2010. Ademas ver Quijano (2000, 2001).

31 Ver Quijano (2001).

32 Aquí estoy importando la idea de “caos”, un concepto de Arrighi para caracterizar los periodos de crisis como condiciones históricas donde el sistema-mundo entra en un caos en su funcionamiento general que implica la necesidad de buscar vías de reconfigurarlo.

33 Estas dos citas proceden de mis notas de la presentacion de Quijano en la conferencia de Instituto Pensamiento y Cultura en America Latina (IPECAL) en la Ciudad de Mexico, Noviembre 5-7, 2010.

34 Ver Houtart (2009). La traduccion es mia.

35 Ver Bernstein. (2009).

36 Esto no quita las contradicciones entre el gobierno presidido por Evo Morales y sectores del movimiento indigena como tampoco las tensiones en la cumbre de Cochabamba que expresan los graves retos y problemas que confrontan los gobiernos que declaran el socialismo del siglo XXI a la vez que siguen siendo estados capitalistas perifericos en un sistema-mundo moderno/colonial capitalista en una era de crisis.

37 Ver Sousa (2006).

38 Estas citas proceden de notas que tome de la presentacion de Lander en el encuentro internacional de la Catedra America Latina y la Colonialidad del Poder en Lima, en Agosto 3-5, 2010.

${ }^{39}$ Ver Peredo Beltrán (2009).

40 Ver Valdes Gutierrez (2010).

41 Lander, ibid. Tambien ver Escobar (2010), y Martinez Alier (2004).

42 Ver Grueso, Rosero y Escobar (1998), y Escobar (2008).

43 Aqui asumimos lo politico como una dimension propia que a la vez esta entrelazada con otras dimensiones de lo social-historico. La especificidad de lo politico y sus articulaciones con lo economico, lo social y lo cultural es un tema harto debatido. Ver especialmente Dussel (2007), Mouffe (2005), Ranciere (2007), y Tapia (2008, 2009).

${ }^{44}$ La razon por la cual coloco comillas en cada una de estas palabras es que cada una de ellas resulta ser de alguna manera problematica. Sin embargo son las palabras claves con las cuales tenemos familiaridad y por eso las usamos aqui aunque con reparos y cautela.

${ }^{45}$ Para un deslinde claro de esta relacion ver Sousa. Dos analisis importantes de las formas de estado en la era neoliberal son Sassen (2010) y Jessop (2008).

46 Ver Fraser (1997).

47 Tilly (1992) plantea una analogia entre los inicios del estado moderno y los modos de funcionamiento de la mafia.

48 Ver Ugarterche (2009).

49 Es interesante observar que despues de que muchos remplazaron la categoria imperialismo con globalizacion, a partir del 2001 con las intervenciones militares en Afghanistan y luego en Iraq se revivio el analisis del poder imperial y emergio una literatura sobre el "nuevo imperialismo estadounidense" tanto critica como apologetica. Entre los textos mas notables estan, Ferguson (2004), Harvey (2005), y Mann (2003).

50 Ver Arrighi (2007)

51 Ver Dussel (1992), Maldonado Torres (2008), y Tortosa (2003).

52 Ver Grandin (2007), Gregory (2004), Mamdani (2005) 
53 Este parrafo se escribe en base de una presentacion de Luis Tapia en un encuentro organizado por el Programa Democracia y Transformacion Global y el Proyecto Movimientos Sociales y Transformaciones Democraticas en el Siglo XXI en America Latina en Lima, Peru entre mayo 25 y junio 3, 2010.

54 Ver, Castro-Gomes y Mendieta (1998), Lander (2005), y Walsh, Shiwy \& Castro-Gomez (2002).

55 Existe una amplia gama de esfuerzos para construir estos modos de produccion y comunicación de conocimientos y sus metodologias y pedagogias. Entre much@s otr@s ver, Hale et al (2008), y Leyva et al (2010). Para el concepto de "insureccion de saberes subyugados" ver Foucault (1980). Para el concepto de "ecologia de saberes" ver Santos (2008). El concepto de "investigacion accion colaborativa" lo desarrolle a partir de mi practica de trabajo con ( y como parte de) los movimientos Afrodescendientes en las Americas y a partir del conceptp de "investigacion accion participativa" de Fals Borda.

56 Ver Santos (2006)

57 Para la nocion de contra-publicos subalternos ver Fraser (1997).

58 Ver Alba Rico (2009)

59 Mientras Maldonado Torres (2008) formula su nocion de la "colonialidad del ser" desde una optica filosofico-existencial, nuestro analisis enfatiza en la dimensiones vivenciales de la des/colonialidad del sujeto y la inter-subjetividad de manera mas afin a los rasgos psicoanaliticos en la obra de Fanon como tambien a la hermeneutica del sujeto historico de Zemelman. Ver Fanon (2009), y Zemelman (2007).

${ }^{60}$ Esta cita procede de notas que tome de la presentacion de Quijano en la conferencia de IPECAL en la ciudad de Mexico, Noviembre 3-5, 2010.

61 El concepto de populismo autoritario fue acunado por Stuart Hall para analizar la cultura politica que sostuvo el regimen neoliberal de Margaret Thatcher en Inglaterra.

62 Asi lo plantea Luis Tapia (2008, 2009).

63 Asi lo plantean Anibal Quijano (2005) y Raul Zibechi (2007).

64 Valdes Gutierrez (2010) formula un concepto de la complejidad del poder muy afin a nuestro concepto de colonialidad del poder.

65 Ver Pratt (1998).

66 En contraste, ver Houtart (2001), quien como uno de los intelectuales organicos mas importantes de la nueva ola de movimientos antisistemicos ha sido organizador del Foro Social de las Alternativas.

67 Ver Santos (2010), y Walsh (2009).

68 Para el debate sobre "La Idea de Comunismo" en la orbita occidental de pensamiento critic over Costas Douzinas y Zizek (2010). Para la discusion sobre lo comun ver Hardt y Negri (2009). Una articulación clave de los imaginarios políticos indígenas es La Sexta Declaracion de la Selva Lacandona.

69 Ver, entre much@s otros: Boyce Davis (2008), James (2006), y Robinson (2000).

70 Ver Bloch (1977), Wallerstein (1998), y Zemelman (1992a, 1992b, 2007)

71 Lugones (2003).

72 Ver Laclau y Mouffe (1985). Nuestro argumento esta informado por el concepto de heterogeneidad histórico-estructural de Quijano.

73 Ver Santos (2006, 2008, 2010).

74 El concepto de re-existir lo aprendimos del intelectual colombiano Adolfo Alban. 


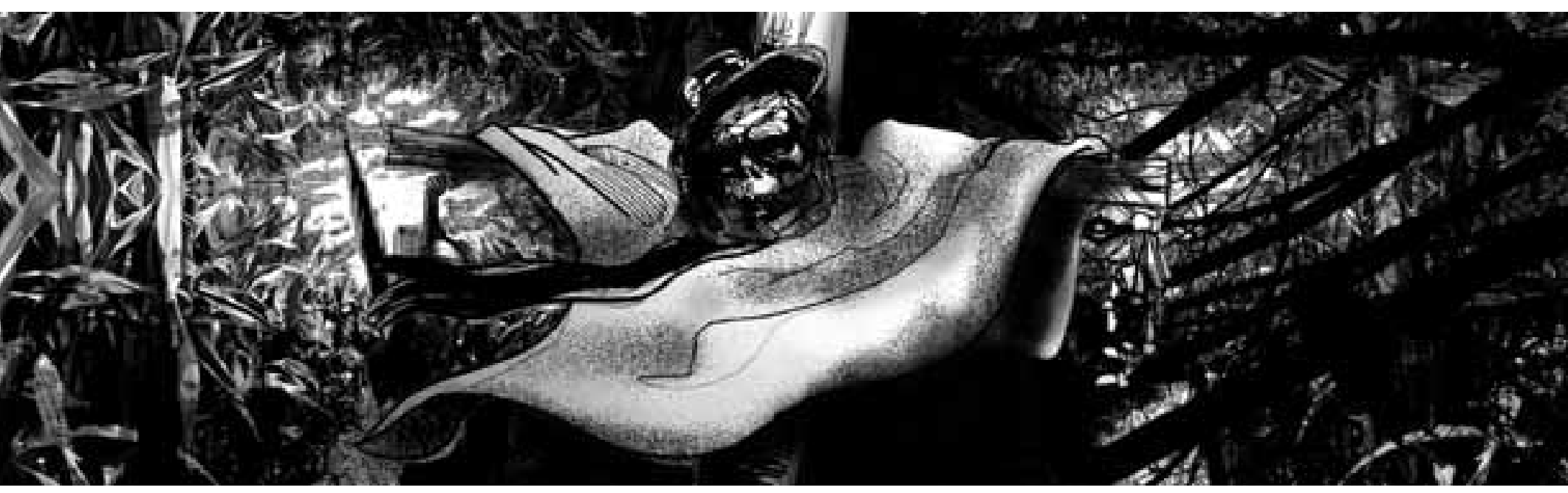

\section{Bibliografía}

Amin, Samir (2009) La Crisis. Salir de la crisis del capitalismo o salir del capitalismo en crisis. El Viejo Topo. Aglietta, Michel (2001). A Theory of Capitalist Regulation:The U.S. Experience. Verso. Arrighi, Giovanni (1999). El Largo Siglo $X X$. Akal. (2007). Adam Smith in Beijiing. Verso.

, Terence Hopkins, e Immanuel Wallerstein (1999).

Movimientos Antisistémicos. Akal.

Bernstein, Jorge (2009). “Acople depresivo global (radicalización de la crisis).” América Latina en Movimiento (Febrero).

Betto, Frei (2009). “Mi nombre es crisis.” América Latina en Movimiento (Marzo).

Bhattacharya, Rajesh (2010).

Bloch, Ernst (1977). El principio esperanza. Aguilar.

Boyce Davis, Carole (2008). Left of Karl Marx:The Political Life of Black Communist Claudia Jones. Duke.

Braudel, Fernand (1992). The Perspective of theWorld. Civilization and Capitalism $15^{\text {th }}-18^{\text {th }}$ Century,Vol III. University of California.

Brenner, Robert (2008). "Lo que es bueno para Goldman Sachs es bueno para América.” (Prologo a la edición castellana) Economía de la Turbulencia Global. Akal.

Callinicos, Alex (2010). Bonfires of Illusions: The Twin Crises of the LiberalWorld. Polity/

Castro-Gómez, Santiago y Eduardo Mendieta, ed (1998). Teorías sin disciplina: Latinoamericanismo, poscolonialidad, y globalización en debate. University of San Francisco

Cesaire, Aime (1955). Discours sur le Colonialisme. Presence Africaine.

Dussel, Enrique (1992). 1492. El encubrimiento del otro: hacia el origen del mito de la modernidad. Antropos 
Hale, Charles R (2008). Engaging Contradicitons: Theory, Politics, and Methods of Activist Scholarship. University of California.

Harvey, David (2005). The New Imperialism. Oxford.

Harvey, David (2010). The Enigma of Capital and the Crises of Capitalism. Oxford.

Huntington, Samuel (1998). The Clash of Civilizations and the Remaking ofWorld Order. Simon \& Schuster.

Houtart, Francois (2001). La Tiranía del Mercado y sus Alternativas. Popular.

Houtart, Francois (2009). "Present and Future Impact of the Crisis." Trabajo presentado en la Conferencia

Crisis Financiera y su Impacto Futuro en el Desarrollo.

Organización de la Naciones Unidas, Nueva York, 23-26 de Junio.

James, CLR (2006). Facing Reality. Charles H Kerr.

Jessop, Bob (2008). State Power:A Strategic-Relational Approach. Blackwell.

Lander, Edgardo (2005). La colonialidad del saber: eurocentrismo y ciencias sociales. CLACSO.

Leyva, Xochutl et el (2010). Conocimientos, Poder, y Practicas Políticas: Reflexiones desde nuestras experiencias de trabajo. (Dos Volúmenes). CIESAS.

Lugones, María (2003). Pilgrimages/Peregrinajes. Theorizing Coalition against Multiple Opressions. Rowman \& Littlefield.

Maldonado-Torres, Nelson (2008) Against War.Views from the Underside of Modernity.

Duke.

Mamdani, Mahmood (2005). Good Muslim, Bad Muslim: America, the ColdWar, and the Roots of Terror. Three Leaves.

Mandel, Ernest (1972). Late Capitalism. Verso.

Mandel, Ernest (1978). The Second Slump: a Marxist Analysis of Recesion in the Seventies.

New Left Books.

Mandel, Ernest (1995). LongWaves of Capitalist Development. Verso.

Mann, Michael (2003). Incoherent Empire. Verso.

Martínez Alier, Joan (2004). El Ecologismo de los Pobres. Conflictos Ambientales y Lenguajes deValoración. Espiritirompa.

Meszaros, Istvan (2010). The Structural Crisis of Capital. Monthly Review Press.

Mouffe, Chantal (2005). On the Political. Routledge.

Negri, Antonio (1996). Marx beyond Marx. Lessons on the Grundrisse. Autonomedia.

Peredo Beltrán, Elizabeth (2010). "Causas estructurales de la crisis climática y la crisis global." América Latina

en Movimiento (Abril).

Pratt, Mary Louise (1998). "Where to? What Next?" n Sonia Alvarez, Evelina Dagnino, \& Arturo Escobar, Ed. Culture of Politics/Politics of Cultures. Re-Visioning Latin American Social Movement. Westview.

Quijano, Aníbal (1988). Modernidad, Identidad y Utopía en América Latina.

Sociedad y Política.

Quijano, Aníbal (2000). “Colonialidad del Poder y Clasificación Social.”

Journal of World Systems Analysis. 
Quijano, Aníbal (2001). Colonialidad del Poder, Globalización, y Democracia.

Manuscrito Inédito.

Quijano, Aníbal (2005). "El Movimiento Indígena y las Cuestiones Pendientes en América Latina." Revista Tareas.

Ranciere, Jaques (2007). On the Shores of Politics. Verso.

Robinson, Cedric (2000). Black Marxism: The Making of the Black Radical Tradition.

University of North Carolina.

Santos, Boaventura de Sousa (2006). The Rise of the Global Left.TheWorld Social Forum and Beyond. Zed.

Santos, Boaventura de Sousa (2008). Conocer desde el Sur. Para una cultura política emancipatoria. Plural.

Santos, Boaventura de Sousa (2010). Refundación del Estado en América Latina. Programa Democracia y Transformación Global.

Sassen, Saskia (2010). Territorio, Autoridad, y Derechos. Katz.

Tapia, Luis (2008). Política Salvaje. Muela del Diablo.

Tapia, Luis (2009). Pensando la democracia geopolíticamente. Muela del Diablo.

Tilly, Charles (1992). Coercion, Capital, and European States: AD 990-1992.

Wiley-Blackwell.

Tortosa, José María (2003) Violencias Ocultadas. Abiayala.

Ugarteche, Oscar (2010). "El Fondo Monetario Europeo y la profundización de la regionalización.” América Latina en Movimiento (Marzo).

Valdés Gutiérrez, Gilberto (2010). Posneoliberalismo y Movimientos Antisistémicos. Letras Cubanas.

Walsh, Catherine, Freda Schiway, y Santiago Castro-Gómez, ed. (2002). Indisciplinar las Ciencias Sociales. Universidad Andina Simón Bolívar y Abiayala.

Walsh, Catherine (2009). Interculturalidad, Estado, y Sociedad. Luchas (de) coloniales de nuestra época. Universidad Andina Simon Bolivar y Abiayala.

Wallerstein, Immanuel (1996). Historical Capitalism with Capitalist Civilization. Verso Wallerstein, Immanuel (1998). Utopistics: Or Historical Choices of the Twenty-First Century. New Press

Wallerstein, Immanuel (2010). "Structural Crises.”New Left Review 62 (March-April) Wolff, Richard D. (2009). Capitalism hits the Fan. The Global Economic Meltdown and What to do about it. Olive Branch.

Zemalman, Hugo (1992a). Los Horizontes de la Razón I: Dialéctica y apropiación del presente. Anthropos.

Zemalman, Hugo (1992b). Los Horizontes de la Razón II: Historia y necesidad de utopía. Anthropos.

Zemelman, Hugo (2007). El ángel de la historia: determinación y autonomía de la condición humana. Anthropos.

Zibechi, Raul (2007). Autonomías y Emancipaciones: América Latina en Movimiento. Programa Democracia y Transformación Global.

Zibechi, Raúl (2010). “Grietas en el Bloque Occidental”. América Latina en Movimiento (Marzo). 